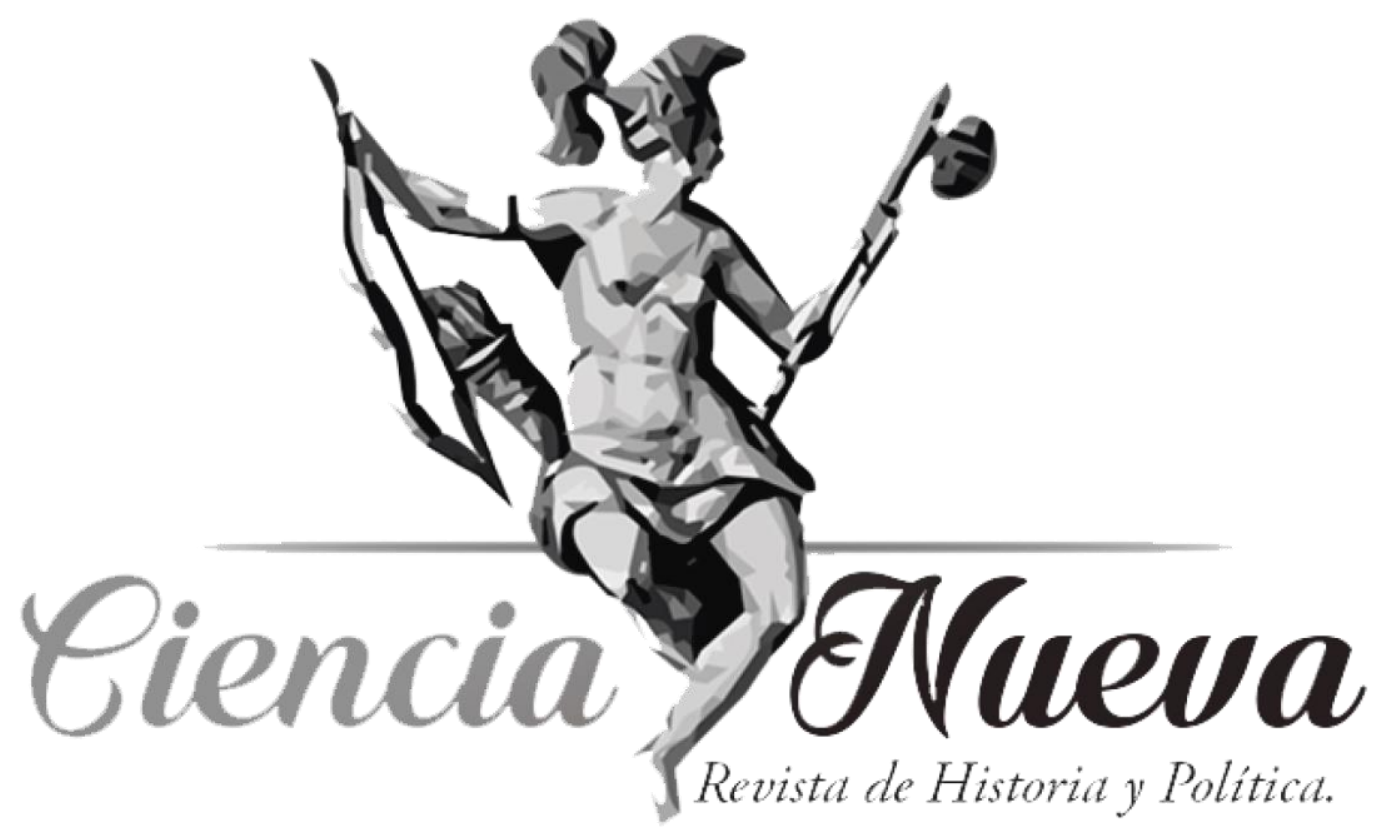

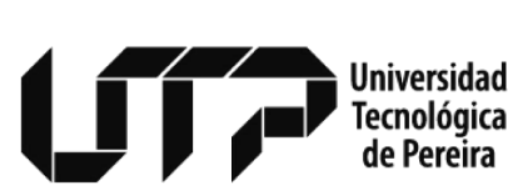

Maestría en Historia

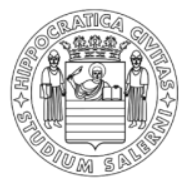

UNIVERSITÀ DEGLI STUDI DI SALERNO

\title{
ESTUDIOS HISTÓRICOS
}

\section{HALLAZGOS DE UN REPORTAJE SOBRE EL TEATRO \\ PEREIRANO}

RESULTS OF A REPORTAGE ABOUT THE THEATER IN PEREIRA

Nathalia Gómez Raigosa

pp. 19-56

Vol. 2 Núm. 2, Julio-Diciembre de 2018

Pereira, Colombia 


\title{
HALLAZGOS DE UN REPORTAJE SOBRE EL TEATRO PEREIRANO* RESULTS OF A REPORTAGE ABOUT THE THEATER IN PEREIRA
}

Nathalia Gómez Raigosa** nathygo89@gmail.com

ORCID: http://orcid.org/0000-0002-0086-308X

\author{
Recibido: 24 de abril de 2018 . \\ Revisado: 20 de agosto de 2018. \\ Aceptado: 10 de septiembre de 2018 . \\ Publicado: 23 de noviembre de 2018.
}

\section{Resumen}

Reportaje del teatro de sala en la escena pereirana es un trabajo panorámico que reconstruye la memoria histórica del movimiento teatral en Pereira desde 1884 a 1990. Se dividen en tres etapas, tanto epistemológicas como estéticas, que buscan configurar lo que ha sido el origen, la evolución y actualidad de esta manifestación artística en la ciudad; pretenden entender su genealogía o las influencias artísticas tejidas entre las diferentes agrupaciones del entramado teatral pereirano y la retroalimentación que puede tener el teatro con otros lenguajes como el cine y la televisión.

La investigación conjuga la metodología historiográfica con las herramientas periodísticas que permite hilvanar fuentes testimoniales con documentales y relacionar el contexto social, económico y cultural de cada acontecimiento. Su espacio geográfico se delimita a Pereira, pero incluye a Dosquebradas por ser parte del perímetro metropolitano de la ciudad. También se hace alusión a otros municipios del territorio risaraldense, que de una $\mathrm{u}$ otra manera entran en conexión con el movimiento teatral pereirano. Así como se analiza el intercambio escénico que los colectivos locales sostienen con ciudades de relevancia en este arte a nivel nacional como: Manizales, Cali, Medellín y Bogotá y su exportación como producto cultural a diferentes partes del mundo.
Si bien la pesquisa se centró en documentar el teatro de sala, también se relacionaron las demás manifestaciones escénicas que han tenido lugar en Pereira como: el teatro de calle, el comunitario, el gestual, los títeres, las marionetas, la pantomima, el clown, las artes circenses, entre otras; pues los colectivos teatrales de la ciudad se han visto obligados a trasmutar de un formato a otro para poder asegurar su subsistencia.

Palabras clave: artes escénicas, historia del teatro colombiano, movimiento teatral pereirano, historiografía, reportaje cultural.

\begin{abstract}
Reportaje del teatro de sala en la escena pereirana is a panoramic workshop that reshuffles the historic memory of the stagy movement in Pereira since 1884 to 1990 . Its divided into three stages both epistemological and aesthetic which try to configure what has been the origin, evolution, and present of this artistic manifestation in the local context; they pretend to understand its genealogy, or its artistics influences woven between the different groups of the lattice of the pereiran theater and the feedback that theater can have with another languages like cine or television.

This research combines the historiographical methodology with the journalistic
\end{abstract}

\footnotetext{
* El presente artículo respeta las directrices y normas dispuestas en la Declaración de Ética de Publicación de Ciencia Nueva, Revista de Historia y Política. Esta declaración puede consultarse en la página web de la revista: revistas.utp.edu.co/index.php/historia. Artículo basado en los resultados de la investigación "Reportaje del teatro de sala en la escena pereirana", ganadora de la beca de investigación en la categoría de periodismo cultural, crónica y reportaje de la Segunda Convocatoria Estímulos 2013, y Mención de honor en la categoría Ensayo de las obras literarias de la Quinta Convocatoria Estímulos 2016. Recientemente publicada como libro en el volumen 44 de la Colección de Escritores Pereiranos 2017 por la Editorial Gráficas Olímpica, diciembre de 2017, ISBN 978-958-59971-2-7.

** Comunicadora social y periodista de la Universidad Católica de Pereira. Magíster en Literatura y estudiante de quinto semestre del Doctorado en Literatura de la Universidad Tecnológica de Pereira. Actualmente tiene una columna teatral en el periódico mensual Ciudad Cultural llamada "La Cuarta Pared".
} 
tools, which allow to baste testimonial documentary sources and relate the social, economic and cultural context of every single event. Its geographic space is focused on Pereira but it also includes Dosquebradas, which is known as part of the city. It also includes some others municipalities of Risaralda which somehow are part of the Pereiran theatrical movement, it's also analyzed the scenic exchange that the local groups have with relevant cities in the national context such as Manizales, Cali, Medellin and Bogotá and its exportation as cultural product to different parts of the world.
Although research was focused on documenting the indoor theater, some other scenic manifestations that have taken place in Pereira were related on it such as street theater, the community theater, the gestural one, puppetry, pantomime, clown, circus, etc.; so, the theatrical groups of the city have been forced to transmute from one format to another one in order to ensure their subsistence.

Keywords: scenic arts; history of Colombian theater; theatrical movement pereirano; historiography; cultural reportage.

\section{Introducción}

- Se puede hablar de una tradición en el teatro de Pereira?, ¿desde qué momento los

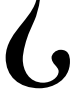
pereiranos incorporaron el teatro en sus prácticas sociales?, ¿quiénes trajeron el teatro hasta la Villa de Robledo?, ¿quiénes han hecho teatro en Pereira y cuáles han sido las motivaciones que los ha llevado a desempeñar el oficio?, ¿qué relevancia ha tenido el teatro en el ámbito local, departamental, nacional e internacional?, ¿qué tipo de escuelas, tipologías y técnicas han trabajado los hacedores de teatro en Pereira?, ¿cómo se está proyectando el teatro pereirano en la actualidad?

Era muy escaso, por no decir nulo, el conocimiento sobre este tema en la ciudad. Hasta hace muy poco las artes escénicas pereiranas no contaban con una historia escrita, por lo que se escuchaba decir con cierta recurrencia que el teatro era una expresión nueva que no tenía mayor influencia en la vida cultural de la ciudad, lo cual según Fernando González Cajiao: "siempre ha constituido el camino más fácil, hasta que alguien tenga la paciencia de hurgar en los viejos manuscritos".

Después de más de cuatro años de arqueología bibliográfica en el que se revisaron archivos institucionales y personales y se entrevistaron a 54 personas, entre teatristas, familiares, gestores, críticos, periodistas, asistentes y funcionarios públicos y privados, que fueron la base para la reconstrucción historiográfica escrita en clave periodística que hoy es el libro Reportaje del teatro de sala en la escena pereirana. Se puede asegurar que el teatro en Pereira tiene un legado, una historia que contar tan antigua que está quizás arraigada en la misma fundación de la ciudad. Pues al tiempo que, en esta aldea, enclavada en el centro occidente colombiano, se fueron irguiendo las primeras construcciones de dos pisos con múltiples propósitos -habitacionales, gubernamentales, bancarios, clericales, hospitalarios, comerciales-, empezaron a nacer planteles educativos y sitios de esparcimiento como parques, clubes y teatros.

\section{De la sábana doméstica al telón rojo}

Asnoraldo Avellaneda Aguilar, un pereirano raizal, que nació en la Pereira del empedrado y la cabalgadura, atestiguó en unas crónicas amenas, que remontan vivencias ocurridas entre 1885 y 1902, lo trascendental que fue para sus coterráneos, la construcción del primer teatro casero.

Como en la actualidad, constituía una, quizá la mejor diversión de la época, el teatro.

Le tocó ser a Ernesto Mogollón el iniciador de este arte en Pereira; era persona 
correctísima, natural de Bogotá, lo instaló en una casa pajiza, situada en la carrera 8 calles 18 y 19, donde más tarde fue el Teatro Caldas, y servía a la vez de Gallera, pues la pista la adaptaba como escenario ${ }^{1}$.

En su cuadro de costumbres, el cronista Avellaneda, continúa refiriéndose a las actividades que se llevaban a cabo en el improvisado teatro de Don Ernesto Mogollón, donde se ofrecían todos los espectáculos que llegaban a la aldea.

Después hizo su debut el espectáculo circeneo (sic) cuyo empresario era el señor Salvini (italiano), que traía como el fuerte de su compañía, un grupo de animales amaestrados que él consideraba sabios. Todo su equipo e instalaciones fue traído a "Lomo de mula" [...] Ya con el correr del tiempo fueron desfilando infinidad de artistas y compañías y así veremos cómo llegan la Cía de Opera española del maestro Luque $^{2}$, el primer prestidigitador argentino, el profesor Soria y la de marionetas (títeres) del Gran Arlequín (italiana) famosa por sus hermosos decorados.

El primer circo de toros fue allí mismo, pero con anterioridad ya la casa había sido adaptada y acondicionada para el acto ${ }^{3}$.

El prosista Avellaneda argumenta que el teatro del señor Mogollón sirvió además como primer zoológico, pues allí exhibía un hermoso tigre que alimentaban con los gallos muertos en las riñas. Es así como finaliza explicando que era "su casa teatro, gallinero, circo, zoológico". En ese tiempo, el teatro albergaba todo tipo de espectáculos comerciales, a donde acudía el público pereirano sediento de conocer el mundo a través de los artistas trashumantes y de sorprenderse con las luces, la música y los artificios presentes en la escena.

Era ese patio polvoriento que como por arte de magia se convertía en teatro, un lugar maravilloso que conectaba la aldea con el exterior, por medio de ornamentos exóticos, música de lugares lejanos, vestimentas coloridas, estilos cautivadores, de extranjeros con diferentes acentos y colores de piel. Visitar estos escenarios artesanales, significaba para el pereirano toda una aventura, muy similar a la narrada en Cien años de soledad, cuando José Arcadio Buendía llevó a sus hijos a conocer los misterios del mundo bajo una carpa gitana.

En un periodo incipiente, cuando las cosas parecían tan nuevas, apenas saliendo del cascarón, en un villorrio con ansias infantiles de volverse grande. Fue en ese poblado, en tiempos finiseculares, cuando tuvieron lugar los autos sacramentales del padre Ismael Valencia en Semana Santa, quien recreaba todo lo relacionado con la pasión y muerte de Cristo, desde la entrada triunfal a Jerusalén hasta la crucifixión en el Calvario. "Y en Navidad alistaba todos los cuadros de la Noche Buena en un tinglado que hacía las veces de pesebre real y escenificaba los momentos más representativos de la llegada del Niño Jesús".

Allí mismo tuvieron cabida las pilatunas, que hoy se conocen como los freaks shows, protagonizados por los díscolos hermanos "Hormacitas" -iniciadores de los espectáculos locales- quienes llegaron a intentar saltar del campanario de la catedral Nuestra Señora de la Pobreza, así como comerse a sangre viva un hombre, con el único fin de animar la curiosidad

\footnotetext{
${ }^{1}$ Asnoraldo Avellaneda, "Pereira del pasado", El Diario, No. 16798, p. 10, 30 de agosto de 1985.

${ }^{2}$ La Compañía Luque fue de las primeras compañías españolas en recorrer el interior del país en la primera mitad del siglo XIX, bajo la dirección de Mariano Luque.

3 Asnoraldo Avellaneda, "Pereira del pasado".
} 
y el espíritu jovial de las multitudes y de paso recolectar dinero para las primeras obras de la naciente ciudad.

En 1916 un editorial del periódico Polidor, semanario crítico-literario dirigido por Obdulio Gómez, advierte la necesidad urgente de edificar un teatro a la altura de una ciudad en ascenso, con el fin de: "contribuir de manera visible al engrandamiento de la tierra y por dar realce al embellecimiento estético del poblado"4. Hasta el momento se contaba solo con espacios teatrales improvisados que no respondían a las especificaciones que exigían las compañías artísticas internacionales que ya empezaban a llegar de gira hasta estos lares, pero que finalmente se cancelaban en último instante, pues Pereira no poseía la infraestructura requerida.

Francisco Mejía Uribe, el hombre más acaudalado de la población y uno de los más pudientes del suroccidente colombiano, decidió que ya era tiempo de pasar de la sábana doméstica al majestuoso telón rojo. Adquirió los predios de la carrera $8^{a}$ entre calles 18 y 19 , que antes le pertenecían a Ernesto Mogollón, y abrió las puertas del primer teatro de la aldea, el Circo-Teatro Caldas, que "servía para la comedia, para el cine y por su dotación especial para el novedoso espectáculo de la corrida nocturna" . Años más tarde su propietario, a quien le decían 'Quico' Mejía, le realizó unos cambios estructurales de modo que pasó de circoteatro a señorial Teatro Caldas, "único lugar de diversión que tenemos en Pereira y que bueno o malo presta el servicio que hoy necesitamos" , anota una columna de opinión de Variedades "revista semanal ilustrada", fundada en 1925.

Dentro de las reformas al establecimiento, estaba contemplada la contratación de un administrador, que primero fue Francisco Antía y después Emilio Vélez L. El Teatro Caldas estaba hecho en madera, contaba con "un formidable equipo parlante de fabricación alemana con proyectores Zeiss Ikon y sistema de sonido Phillips"7. Tenía capacidad para 1325 personas que se acomodaban en tres galerías circulares y un palco reservado para personas que estuvieran de luto, con un visillo especial por donde podían mirar el espectáculo sin ser vistos por el público. Ya no se realizaban las corridas nocturnas, pues el patio de lidia se había entablado y convertido en una platea con 400 butacas y corredores alternos, para los espectadores especiales. Además, fue "dotado de camerinos para actores, escenario para actuación y parrilla para el movimiento de decorados y telones"8.

Estamos hablando de esos años cuando el teatro tenía que turnarse con el cine mudo, para poder ocupar el escenario del Teatro Caldas, los miércoles y sábados, días de mercado en la polvorosa Plaza de Bolívar. En "El Caldas" se presentaron compañías teatrales procedentes del antiguo mundo, países hispanoamericanos y otras ciudades de Colombia, que arribaron para dar a conocer sus comedias, operas, zarzuelas, revistas y dramas. Luciano García, otro de los cronistas de esa época remota, relató la presentación de la compañía mexicana de revistas Lupe Rivas Cacho, que fue tachada en Pereira de inmoral y escandalosa, pues sus bailarinas se presentaban con vestuarios diminutos e incluso había escenas despojadas de todo tipo de atuendo.

\footnotetext{
${ }^{4}$ Obdulio Gómez C, "Necesidades de Pereira”, El Polidor, No. 18, 4 de marzo de 1916.

${ }^{5}$ Luis Carlos González, Retocando imágenes: 33 crónicas del Pereira Antiguo (Pereira: Fondo Editorial de la Gobernación de Risaralda, 1984), 59.

${ }^{6}$ Emilio Correa Uribe, "Confetti XVI", Variedades, No. 64, 8 de mayo de 1926.

${ }^{7}$ Emilio Correa Uribe, “Teatro Caldas", El Diario, No. 2000, 30 de septiembre de 1935.

${ }^{8}$ González, Retocando imágenes..., 49.
} 


\section{En Pereira se cruzan los caminos del arte}

Estos artistas errabundos se veían obligados a enfrentarse a extenuantes travesías, mientras realizaban sus giras internacionales, que incluían viaje en barco, en tren y a lomo de mula, pues los caminos aún eran de trocha y arriería. El costumbrismo extranjerizante se imponía como una segunda colonización europea, pero al mismo tiempo por ser pintoresco, folclórico y por tener esa forma tan parroquial de ver la vida, se convirtió en caldo de cultivo para acercar a la bisoña Pereira con el arte. De manera que sembró en los jóvenes del municipio el deseo de agruparse y de llevar hasta las tablas las representaciones tan afines a las vivencias simples del poblado.

La primera expresión teatral local de la que se tiene registro son los cuadros vivos que el profesor Benjamín Tejada Córdoba montaba, se presume, con los estudiantes del Instituto Manuel Murillo Toro. Uno de ellos realizado, entre 1915-1918 aproximadamente, fue inspirado en la Gran Guerra Europea, "cuando hasta nosotros llegaban noticias que anunciaban el horror de sus combates", aclara un artículo de El Diario que años después rememora la labor del cultor. Entre los actores de la estampa se puede identificar un niño, en la esquina inferior izquierda. Ese pequeño era Fernando Jaramillo Ángel, quien más tarde sería protagonista de la primera película grabada en estas tierras.

\section{Nido de teatro y cine}

Hablo del desaparecido largometraje silente, Nido de Cóndores, del cual únicamente se conserva un fotograma, que se ha convertido en la obsesión de muchos historiadores. La cinta tenía el único fin de "mostrar el origen, progreso y adelanto de Pereira, fue producida por la Sociedad de Mejoras de Pereira y fue filmada creo que en 1926"10, aseguró el camarógrafo español Máximo Calvo, quien la dirigió con el apoyo del reconocido empresario cinematográfico Nicolás di Doménico.

El guion fue escrito por Alfonso Mejía Robledo, primer novelista de la imberbe ciudad e interpretado por los integrantes del Grupo Escénico, primer colectivo del teatro local que se advierte en 1925. Esta agrupación estaba conformada por: Tulia Drews, Teresa Restrepo, Anita e Inés Rendón Bustamante, Olga Sierra, Concha Vélez, Antonio Gómez Villegas, Gonzalo Martínez, Abelardo Echeverry, Fernando Jaramillo, Luis Eduardo Marulanda, Mariela Gutiérrez, Enrique Aristizábal Moreno y Emilio Correa Uribe. Jóvenes entre los 19 y 24 años quienes pertenecían a la crema y nata de la sociedad, ya que sus padres o ellos mismos eran los patrocinadores de obras arquitectónicas e institucionales que abanderaban el desarrollo del municipio ${ }^{11}$.

Los repentinos aficionados al teatro fueron convocados por "la entusiasta e inteligente Justina González González,"12, quien tomó la dirección acompañada por Pedro Piedrahíta, el apuntador. El Grupo Escénico "tenía por objeto el montaje de piezas teatrales con el ánimo de recaudar fondos destinados a la realización de obras de importancia general"13. Las obras teatrales del colectivo completaron la oferta cultural, principalmente de las kermeses, fiestas

\footnotetext{
${ }^{9}$ Emilio Correa Uribe, “Teatro Caldas”, El Diario, No. 2000, 30 de septiembre de 1935.

${ }^{10}$ Hernando Salcedo Silva, Crónicas del cine colombiano, 1897-1950 (Bogotá: Carlos Valencia Editores, 1971), 71.

${ }^{11}$ Información recolectada gracias a las revistas de la época Lengua y Raza y Variedades y a la investigación de Rigoberto Gil Montoya, Nido de Cóndores: aspectos de la vida cotidiana de Pereira en los años veinte (Bogotá: Ministerio de Cultura, 2002).

${ }^{12}$ González, Retocando imágenes..., 125.

${ }^{13}$ González, Retocando imágenes..., 125.
} 
benéficas de "Derroche de lujo, de gracia, de dinero"14, tal como lo anota la columna social "Confetti" de la revista Variedades.

\section{Al recio empuje del teatro}

Entre su repertorio figuraba obras como: Fuego extraño, original del famoso dramaturgo colombiano Antonio Álvarez Lleras, montaje que colaboró a la construcción del asilo de ancianos. Después vendría Puñao de rosas, escrita por Carlos Arniches. Luego Rima eterna de los hermanos Álvarez-Quintero; más adelante serían recordados por las representaciones de Juventud y Abandono, estas dos últimas del poeta antioqueño Alejandro Mesa Nicholls, entre otras.

Se puede inferir que no era el amor por el arte o las búsquedas estéticas lo que impulsaba a los emprendedores artistas del Grupo Escénico, sino el bienestar común y el sentido de cooperación. Sin embargo, estas gentes con su esperanza visionaria cultivaron, sin querer, una inquietud por la manifestación teatral y por acercarse a los autores del llamado teatro burgués.

Como bien lo explica Luis Carlos González en sus crónicas sobre el movimiento escénico de la época, "motivo permanente de acercamiento social y fuente inagotable de recursos destinados a necesidades comunes fueron siempre bazares, becerradas, recitales, veladas artísticas y representaciones teatrales" ${ }^{15}$. Es el caso de la Diócesis de Pereira, que pudo llegar a feliz término, gracias al grupo teatral que en 1954 dirigió de nuevo Justina González, quien llevó hasta el escenario la comedia Una obra de beneficencia, escrita por la dama pereirana Sofía Ospina de Navarro. Es importante mencionar esta producción teatral no tanto por la obra misma, que entra a engrosar la lista de presentaciones filantrópicas, sino porque estaríamos, posiblemente, frente al origen de la dramaturgia pereirana.

Del mismo modo en 1960, distinguidas personalidades de Pereira, integraron un nuevo grupo de teatro, esta vez a beneficio de los trabajos iniciales de la Villa Olímpica. La obra presentada en el Teatro Caldas fue La nиеva ola, dirigida por Enrique Valencia Martínez y escrita de nuevo por una dramaturga de la ciudad, Eucaris Jaramillo de Uribe.

En 1961 los "Amigos del arte" organizaron otra exhibición teatral en el Teatro Caldas con el fin de reforzar los fondos de la Villa Olímpica. Cerca de mil personas apreciaron la obra El traje azul de Ciro Mendía, interpretada por una agrupación que se hacía llamar Grupo Escénico, en honor a la actividad teatral de antaño. El nuevo Grupo Escénico estaba conformado por: Amanda Mejía Nauffal, Rosina Molina, Ricardo Mejía Isaza, Edilma Escobar de Cardona y Samuel Arango J. y dirigido por la española Catalina Font de Gómez, quien arribó a la ciudad el 13 de octubre de 1958 y se incorporó, casi de inmediato, a la actividad teatral local.

La directora Font había creado una cátedra de teatro al interior de la Sociedad "Amigos del Arte", que hasta ese momento únicamente había tenido profesores itinerantes en la práctica de esta manifestación artística. Conformó dos grupos: el Teatro Experimental de Pereira para adultos y el Teatro Escuela para jóvenes, con los que realizó presentaciones no solo en las instalaciones de la entidad, sino también en los diferentes escenarios culturales de Pereira y hasta de la región.

\footnotetext{
${ }^{14}$ Emilio Correa Uribe, “La bellísima Kermesse del martes en la Plaza de Bolívar”, Variedades, No. 124, p. 13, 2 de julio de 1927.

15 González, Retocando imágenes..., 125.
} 
Algunas de las obras montadas fueron: Amable señor viveros de Alberto Dow, El gallo cantó tres veces de la antioqueña Regina Mejía, Los sordos del argentino German Berdiales, La consagración de la noche de Jean Tardieu, Demanda en la casa cural de Pimentel y Vargas, A la salida de Luigi Pirandello ${ }^{16}$ y Arrayanes y mortiños de Ciro Mendía $^{17}$.

Fue tanto el éxito que tuvieron estos grupos que llegaron a oídos de Luis Enrique Osorio, fundador de la comedía nacional e iniciador en la investigación de las artes escénicas en Colombia, quien intrigado por rumores que hablaban de que en Pereira se vivía un momento vital en el teatro de la región, decidió viajar a la "Capital Cívica de Colombia” para ver con sus propios ojos lo que estaba ocurriendo. Llegó en diciembre de 1964 para participar de un acto cultural que describió con estas palabras:

Me enteré, ante todo, de que en el ambiente social (pereirano) bullía el ingenio y el humor que hubo en el Bogotá de hace medio siglo, cuando en los hogares del expresidente Marroquín aún se representaban comedias para festejo de los cumpleaños y se bailaba luego hasta el amanecer [...] Algo semejante ocurrió aquí entre ruidosas carcajadas en los salones del Gran Hotel cuando a la sobremesa de la comida algunas damas desplegaron su ingenio improvisando sainetes que esbozaban cuadros de costumbres donde se remedaba el acento sirio-libanés y hasta se exageraba el antioqueño ${ }^{18}$.

El trabajo de Catalina Font ${ }^{19}$ también mereció el reconocimiento del crítico Osorio, quien dijo que la directora sabía "combinar muy bien el fomento del arte escénico colombiano con la apreciación de obras de famosos autores extranjeros"20.

Dentro del extraviado legado de la Sociedad de Amigos del Arte en su primera etapa, hay que resaltar también el grupo de títeres Jim 's Patelin dirigido por Nevert Londoño, donde se diseñaron muñecos, decorados e incluso se escribieron varios libretos. Asimismo, el grupo Pinocho de teatro infantil, creado en 1970 por Rossina Molina, quien había pasado de aprendiz de teatro a profesora, después de estudiar con Font Vallbona y luego de formarse durante tres años con Antonietta Mércuri, en el programa de extensión cultural del Instituto de Bellas Artes de la Universidad Tecnológica de Pereira (UTP).

Con "Amigos del Arte" finalizamos un periodo mimético, que encontraba en la reproducción de lo ajeno la única respuesta. Los espectadores de entonces, estaban padeciendo el tedio de años de repetición y bostezaban ante las mismas recetas del "teatro visita" ${ }^{21}$. Era tiempo de cambiar el menú, con la creación de movimientos, montajes escénicos y dramaturgias autóctonas que construyeran una identidad desde lo que éramos y representaran los asuntos colombianos.

\footnotetext{
16 Esta información se pudo establecer gracias a que la alumna Alba Lucía Jaramillo conservaba una programación teatral del Teatro Escuela en su álbum familiar.

${ }^{17}$ Pilar Gómez Font, en entrevista vía correo electrónico, Madrid, 12 de septiembre de 2013.

${ }^{18}$ Luis Enrique Osorio, “Artistas de Pereira”, El Tiempo Teatro, Vida cultural (S.F pero se estima que pudo haberse publicado entre diciembre del 1964 a mayo de 1965).

19 El 21 de mayo de 1966, Catalina Font de Gómez regresó a España con su familia.

${ }^{20}$ Luis Enrique Osorio, “Teatro”, El Tiempo Vida cultural, 15 de noviembre de 1964, noviembre.

21 Este término era utilizado por Santiago García para referirse de forma irónica a ese tipo de teatro especialmente burgués, tan parecido a lo que en la actualidad se presenta en la televisión. Santiago García, Teoría y práctica del teatro (Bogotá: Editorial Colombia Nueva, Editores Ceis, 1983).
} 
Para alcanzar esos ideales, había que ir contra del teatro de corte español, declamatorio y de estilo costumbrista, que evadía la reflexión desde la escena e ignoraba los últimos desenvolvimientos teatrales en el resto del mundo. Los susurros del inconformismo y la rebeldía mundial resonarían en nuevas formas de teatralidad, que se sinterizaron en una expresión de renovación, El Nuevo Teatro ${ }^{22}$.

\section{De Pereira para el mundo}

Esas resonancias llegaron hasta el movimiento pereirano gracias a que en 1977 Eduardo López Jaramillo, secretario ejecutivo la Sociedad de Amigos de Arte en su segunda etapa, realizara el Primer Festival Internacional de Teatro por medio del cual los ciudadanos pudieron contemplar en el Polideportivo (hoy Coliseo Menor) las agrupaciones: Rajatabla de Venezuela, El Galpón de Uruguay, La Comuna de Portugal, Arteón de Argentina, la compañía Mimos con actores de Uruguay y Francia y los colectivos españoles: El Búho y El Albaicín $^{23}$.

Se trataba de una coyuntura única, pues el Festival Internacional de Teatro de Manizales $^{24}$ pasaba por una profunda crisis económica y logística que obligó a suspenderlo por diez años a partir de 1972. Además, existían gestores nacionales interesados en trasladar, el festival de la capital caldense para Bogotá. Así que la muestra teatral de Pereira buscaba asumir el desafío de convertirse en un referente de la cultura nacional y de paso, controvertir la medida centralista.

Todos los grupos participantes tenían un perfil y unas luchas muy similares: realizaban un trabajo independiente; sus obras trataban de representar la realidad del país o de una época específica, lejos de ser consideradas comerciales o de entretenimiento; la injusticia y la desigualdad eran tropos recurrentes en su dramaturgia y el Estado no les apoyaba, sino que por el contrario perseguía u obstaculizaba su actividad.

Fue solo hasta 1979, Año Internacional de la Niñez, proclamado por la ONU, cuando la Sociedad quiso impulsar otro festival internacional, esta vez de teatro infantil, que iba a tener como sede principal a Pereira, pero que se planeaba desplazar a los municipios de Risaralda y Quindío, durante mayo y junio de ese año. Sin embargo, solo pudieron realizarse dos funciones de la agrupación Trabalenguas de Madrid y el evento tuvo que ser cancelado por la irresponsabilidad de un funcionario que hacía las conexiones aéreas de los artistas.

\footnotetext{
${ }^{22}$ El Nuevo Teatro según los historiadores fue el período comprendido entre 1965 y 1985 (aproximadamente). Según conceptualiza María Mercedes Jaramillo en su libro Nuevo Teatro Colombiano: arte y política, este movimiento, "reflejó los cambios políticos y sociales que vivía el país y se captaban en su vida cultural. [...] es la concretización de una cultura popular que ha sabido resistir a través de los años: la discriminación, la marginación y la represión ejercida por la cultura oficial dominante; que ha controlado todos los medios de comunicación, que han regulado los programas educativos y que ha definido la política cultural nacional”. María Mercedes Jaramillo, El Nuevo Teatro colombiano: arte y política (Medellín: Universidad de Antioquia, 1992), 346.

${ }^{23}$ Esta información se pudo establecer gracias al hallazgo del volante oficial del festival encontrado en los archivos de la Sociedad Amigos del Arte que se almacena a su vez en la Academia Pereirana de Historia.

${ }^{24}$ En el 1968 se creó el Festival de Teatro de Manizales que acogió los grupos más destacados de América Latina e ilustres invitados como Pablo Neruda, Ernesto Sábato, Mario Vargas Llosa, Miguel Ángel Asturias, Jack Lang y Jerzy Grotowski, entre otros. Tras cinco ediciones el festival de Manizales quedó clausurado puesto que su irreverencia y contestataria tendencia terminó por escandalizar a la tradicional población manizalita. Catalina Esquivel, "Teatro La Candelaria: Rasgos de una Dramaturgia Nacional” (Tesis doctoral, Universidad

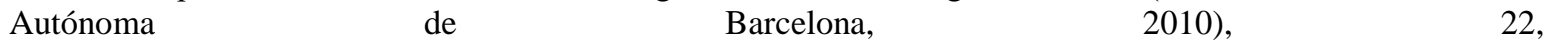
https://ddd.uab.cat/pub/trerecpro/2010/hdl_2072_97278/Catalina_Esquivel.pdf.
} 


\section{Antonieta Mércuri, una mamá grande}

Mientras tanto el ambiente teatral pereirano se caldeaba con personajes como Antonietta Mércuri, quien había llegado a la ciudad en 1968 tras haber estudiado actuación y dirección en Roma, en la Academia Nacional de Arte Dramático de Silvio D' Amico y en otras instituciones especializadas en artes escénicas, por medio de una beca del ICETEX, otorgada por haber ganado el puesto a la mejor actriz de carácter en el Primer Festival Nacional de Teatro, galardón que le arrebató a la recién llegada de Argentina, Fanny Mikey.

Mércuri estaba interesada en apoyar el movimiento de teatro estudiantil desde la UTP. Conformó un colectivo que al comienzo se llamaba Grupo de Teatro de la Universidad Tecnológica (TUT), pero después pasó a ser Los Juglares, como un acto de rebeldía ante las limitaciones de espacio impuestas por María Teresa Salazar de la Cuesta, directora del Instituto de Bellas Artes, quien los obligaban a rodar por Pereira en busca de sitios prestados para poder ensayar, "como si se tratara de comediantes la Edad Media"25.

Los Juglares iban y venían por todo Risaralda, Caldas y Valle, pues en un día podían realizar hasta dos o tres funciones. Utilizaban su tiempo libre para ensayar jornadas extenuantes, sacaban de su bolsillo para transportarse y elaborar vestuarios y escenografías. Realizaron más de 40 montajes, algunos con textos adaptados, otras adaptaciones propias, creaciones colectivas ${ }^{26}$, procesos de investigación in situ y de participación del público. Tuvieron muchas presentaciones en colegios, cárceles, veredas, sindicatos, universidades, festivales, plazas, teatros, barriadas de invasión, huelgas universitarias, paros obreros, fábricas y calles.

José Fernando Marín, integrante de Los Juglares, además sostiene que con Antonietta, llega por primera vez a Pereira el método Stanislavski, así como la técnica de distanciamiento de Bertoldt Brecht. El mundo no conocía aún el Teatro Pobre de Jerzy Growtoski y Antonietta ya lo trabajaba con sus puestas en escena minimalistas. "El teatro de arena ${ }^{27}$ que se planteaba en otros países como propuesta, nosotros lo encontramos por necesidad" 28 , sostiene Reina Sánchez, otra de sus alumnas.

El mayor incentivo que tenía la profesora Mércuri para continuar su trabajo en la UTP, era fundar una licenciatura en artes escénicas, como se había hecho con los programas de música y artes plásticas, o por lo menos una escuela de teatro, aspiración que Jorge Roa Martínez, también profesó al fundar la alma mater. Sin embargo, nunca se logró consolidar, por lo que la docente renunció en 1981 después de 12 años de trabajo continuo, alegando acoso y represión laboral por parte de su jefe inmediata, María Teresa de la Cuesta.

El no reintegro de Antonietta a la UTP causó la indignación del gremio cultural de la ciudad y la mítica toma a la Iglesia San Antonio María de Claret, por parte de los estudiantes, como fue registrado en el periódico La Tarde el 11 de junio de 1981, bajo el título de "Graves

\footnotetext{
${ }^{25}$ Redacción El Reportero, "El grupo teatral juglares, una vida, en trabajo, una meta", El Reportero, diciembre de 1979.

${ }^{26}$ La creación colectiva es un baluarte del patrimonio cultural multiétnico de América Latina, pero sin negar la tradición clásica teatral o los aportes técnicos de otros grupos teatrales europeos o estadounidenses. Respondió al deseo de llegar a un público popular. Este hecho obligó a la gente del teatro a representar obras que reflejaran los conflictos cotidianos, a nutrirse de fuentes vivas de la cultura, el folklore, las creencias populares y a recoger los hechos históricos determinantes en la vida de cada país. Jaramillo, El Nuevo Teatro colombiano: arte y política..., 93.

${ }^{27}$ El Teatro de arena es una técnica originaria de Sao Pablo (Brasil) a mediados del siglo XX, tiene por objeto la economía del espectáculo, no se utilizan escenarios, sino que se actúa en locales improvisados en forma circular.

${ }^{28}$ Reina Sánchez, entrevista vía correo electrónico, Bogotá, 21de octubre de 2013.
} 
disturbios protagonizaron los estudiantes de la U. Tecnológica”. Algunos de los actores de Los Juglares ingresaron al grupo de Gustavo Rivera, mientras a Mércuri le conseguían reemplazo en su cátedra.

\section{Gustavo Rivera, el patriarca}

Casi paralela a la actividad de Mércuri estaba la de Gustavo Rivera, originario de La Celia (Risaralda), quien se había hecho director de teatro después de haber recibido en sus años de juventud las enseñanzas del maestro Enrique Buenaventura, mientras este "adelantaba talleres con los actores juveniles más aventajados del Valle del Cauca" 29 . Al llegar Rivera a la ciudad en 1971, corrió con la suerte de que estaban necesitando un director para el grupo de Teatro de la Universidad del Risaralda, hoy Universidad Católica de Pereira, que había sido dirigido hasta ese momento por Gustavo Orrego y Francisco González Lotero, poeta pereirano.

En un mes maratónico, Rivera montó Fusiles del sol, obra de su autoría estrenada el 5 de octubre 1971 en la sede de la alma mater. Por tan excelente desempeño fue llamado a liderar la agrupación de teatro del ahora reducido, Instituto Departamental de Cultura, donde además dirigió talleres en todas las casas de la cultura de los municipios risaraldenses, por medio de la Extensión Cultural del departamento.

En 1986 nació Nueva Escena, después de que despidieran la planta de trabajadores de Extensión Cultural, por malversación de fondos, lo cual, según Juan Carlos Londoño, alumno de Gustavo fue: "un pretexto politiquero para sacarlos del sistema" ${ }^{30}$.

En toda su trayectoria, el grupo de teatro del maestro Rivera montó 21 obras, casi todas a partir de la creación colectiva. En el aula, la práctica siempre estuvo transversalizada por la teoría que el director Rivera había acumulado a lo largo de su vida, con los múltiples diplomados y cursos en dramaturgia, estética y crítica teatral, pero también a partir de su formación autodidacta, pues, con obsesión, se enfrenta hasta hoy a textos marxistas y a los grandes teóricos del teatro universal.

Tanto Mércuri como Rivera sirvieron de universidad para que los colegiales, de la década de los setenta, se convirtieran en directores adelantados, que se atomizaron en diferentes agrupaciones tales como: Nuevo Horizonte de José Helmer Zapata, Sol Naciente de Herman Marín, Prosopón de Jaime González, Alcaraván de Miguel Ángel Quintero, La Cometa de Reina Sanchez, el Solar de Pacho Tejada, San Basilio de palenque de Omar Ramírez, Palo Q' Sea de Jaime González, quienes a su vez formaron otros artistas. Pues a falta de educación formal que se ocupe del teatro en la ciudad, sus actores se educan en las tablas y en las vicisitudes que les va deparando el camino.

\section{Lo que se hereda no se hurta}

También fue fundamental para la consolidación del entramado teatral, el asentamiento del colectivo La Parca de Bogotá, liderado por Álvaro Bayona. Este director sembró el germen del teatro estudiantil con la creación de la Muestra Departamental de Teatro Intercolegiado. Además, logró lo increíble: que un grupo pereirano se codeara con lo mejor del teatro de diversos países en el Festival Internacional de Teatro de Manizales.

Pero, sin duda, las barreras de la utopía para el arte de provincia fueron franqueadas por Palo Q' Sea. No solo escalaron con sus obras de teatro callejero y pantomímico hasta el

\footnotetext{
${ }^{29}$ Gustavo Rivera, en entrevista personal, Pereira, 28 de mayo de 2013.

30 Juan Carlos Londoño, en entrevista personal, Pereira, 23 de febrero de 2013.
} 
Festival Iberoamericano de Teatro de Bogotá, sino que conquistaron el afecto de públicos de muchas latitudes con sus legendarios pasacalles. Era un grupo conformado por hijos de familias numerosas, con escasas posibilidades de cualificarse profesionalmente y quienes creían que la fama solo era posible para los actores de la televisión. Aun así, lo que hicieron algunos de los integrantes de Palo Q' Sea, constituye una hazaña que le abrió la mente a todo el gremio, para quienes, hasta ese momento, salir de gira con su arte al exterior era impensable.

La década de los ochenta, con su explosión de festivales, depuró de imperativos categóricos la escena y relativizó la verdad que el teatro dialéctico había vendido como absoluta e inmutable, por medio de las nuevas líneas teatrales de vanguardia que trajeron consigo las agrupaciones extranjeras. Se pasó de trabajar las radicales posturas de Bertolt Brecht, a perspectivas desacralizadoras como el teatro de la crueldad de Antonin Artaud y de la muerte de Tadeuz Kantor, por mencionar algunas.

\section{La generación de transición y la Nueva sangre}

Los años noventa todavía son muy cercanos a nosotros para analizarlos en perspectiva, pero en Pereira parecen haber tenido un matiz singular. Los grupos que nacieron en esa etapa se vieron enfrentados a tres opciones: hacer teatro a la sombra de Palo Q' Sea, a partir de Palo Q' Sea o a pesar del mismo. El fenómeno que implicó la agrupación callejera, en cierto sentido eclipsó a los demás grupos que apenas enfrentaban el vacío que había dejado en el ambiente cultural el Teatro La Parca.

Pero tal vez los tres acontecimientos de la década del noventa que proyectaron con más firmeza el movimiento local fueron: primero, la cúspide que alcanzó el Festival Metropolitano Intercolegiado de Teatro ${ }^{31}$, organizado por la Corporación Biblioteca Pública y Comfamiliar Risaralda. De allí surgieron directores destacados como Juan Carlos Londoño, Carlos Vicente Sánchez y Andrés Galeano. Segundo, la creación del Grupo Escuela fundado por Claudia López, un programa de formación a cinco semestres con estructura de colectivo, respaldado por el Instituto de Cultura de Pereira. Y tercero, la conformación del Grupo Cultural y Artístico La Moira ${ }^{32}$, dirigido por René Fernando Chisco, del que emergieron los directores: Diego Hernando Restrepo del Taller Lúdico Creativo, Juan Pablo García de RoKaDa Teatro, Miguel Ángel Rodríguez del Teatro Taller de La Memoria, Diego Leandro Marín del desaparecido Imaginario Teatro, Wilmar Ramírez de Paradigma Teatral, entre otros.

Asimismo, el terremoto ocurrido en el Eje Cafetero en 1999 y el cambio de milenio, produjeron una metamorfosis en las artes escénicas locales que pasaron de la generación de transición a la etapa identificada bajo el apelativo de la Nueva sangre. Pereira vio nacer en el 2000 la agrupación teatral más insolente de su breve historia: Los Idiotas Teatro, dirigida por Andrés Galeano, en compañía de Mauricio Robledo. Unos jóvenes muy permeados por el séptimo arte, la literatura oscura de Charles Bukowski, la filosofía de Emil Ciorán y la ironía del dramaturgo francés Jean Tardieu. Este colectivo, que hacía en el escenario lo que se le

\footnotetext{
${ }^{31}$ Esta muestra en el 2014 llegó a su vigésima cuarta versión, liderada por la Red de Teatro Estudiantil. Cambió su nombre a Festival Metropolitano de Teatro de las Aulas a las Tablas, para dar cabida a colegios, universidades, escuelas de formación artística de carácter público y privado en el Área Metropolitana Centro Occidente.

32 Jaime Manzur le enseñó el arte de las marionetas a René Fernando Chisco, con el que La Moira se diferenció de los demás grupo pereiranos.
} 
daba la gana, logró volcar a las salas una cantidad asombrosa de adolescentes que se identificaron con sus comedias corrosivas, donde prevalecía el sin sentido y el humor negro.

Se sospecha que el estilo ácido de Los Idiotas Teatro indujo a un cambio de paradigma en los colectivos posteriores. La Nueva sangre o los teatristas de la era de la globalización crecieron con los viodeojuegos, el computador y todos los géneros cinematográficos, en una realidad contradictoria y no claramente delineada, como la que se respiraba en el teatro épico. Las dinámicas digitales se ven reflejadas en sus puestas en escena que le apuntan a lo multimedia, donde se mezclan recursos tecnológicos, efectos especiales, de iluminación y sonido. De igual forma, el internet y las redes sociales terminaron con el ostracismo de los años noventa al facilitar la promoción de las obras, la gestión de los proyectos y el contacto con la comunidad teatral por fuera de los ámbitos locales y nacionales.

\section{A modo de conclusión}

Estos son a grandes brochazos los hallazgos que responden en cierta medida los cuestionamientos que nos hicimos inicialmente: ¿De dónde viene el teatro pereirano?, ¿cómo se ha configurado el movimiento teatral en su historia?, ¿es posible hablar de tradición del oficio de las tablas en la ciudad?

A mi modo de ver estas preguntas no se habían podido responder por la existencia de una brecha generacional. Un abismo que separa a los teatreros primigenios, pertenecientes a la élite pereirana, con los trabajadores modernos que transformaron esta actividad comercial en una apuesta política y con la camada de jóvenes que experimentan con lenguajes contemporáneos y han podido llevar el teatro pereirano a diferentes escenarios nacionales e internacionales.

Esa asidua negación entre los teatristas de ayer y los de hoy, ha impedido que los actores que han girado en torno al hecho teatral de la ciudad, en sus diferentes épocas, se reconozcan, sepan de dónde vienen, cómo su trabajo ha sido influido o ha servido de canon para los demás. Aquí quiero citar de nuevo a Fernando González Cajiao, cuando dice: "No es lo mismo la carencia de identidad cultural que la ausencia de tradiciones culturales"33.

Hay que pensar en Reportaje del teatro de sala en la escena pereirana como apertura para futuras pesquisas, pues este collage solo alcanza a llegar hasta 1980. Por lo que solo hace un análisis general de los años que sigue, una década muy relevante de analizar, pues es cuando se logra un mayor despliegue de las artes escénicas del municipio.

También estamos en mora de analizar la dramaturgia local, existen numerosos autores de nuestro teatro que no han sido tenidos en cuenta en los estudios literarios regionales, entre los que se encuentran: Lisímaco Salazar con tres obras operáticas y dos comedias; las piezas de las damas cívicas, Eucaris Jaramillo y Temis Pardo; la reconocida escritora Alba Lucía Ángel, con dos obras inéditas; el teatro de corte político escrito por Antonietta Mércuri y Gustavo Rivera y Jairo Santa con sus textos infantiles, por mencionar algunos nombres del inexplorado mundo de las letras del teatro.

A las administraciones municipales y departamentales le ha faltado mayor acción a la hora de apoyar los procesos artísticos de la ciudad. Si bien en los últimos años se ha generado una nueva conciencia sobre la necesidad de desarrollar y cualificar la oferta cultural, el arte en general continúa relegado -a un plano secundario o terciario-dentro de la formulación de políticas públicas por parte del Estado y la dirigencia empresarial. Prevalece la mentalidad prejuiciosa y reduccionista que tiende a subvalorar los productos culturales como simple

\footnotetext{
${ }^{33}$ Fernando González Cajiao, Historia del teatro en Colombia (Bogotá: Colcultura, 1986), 25.
} 
divertimento para llenar la programación de la fiesta popular, y no como un valioso dispositivo para la reflexión tanto ontológica como axiológica de la relación del ser humano y el entorno.

De la misma manera la academia, en especial la Universidad Tecnológica de Pereira, tiene una deuda muy grande con las artes escénicas locales, pues la escuela de teatro no se ha podido consolidar pese a la lucha incansable que dio Antonietta Mercuri por instaurarla durante los años setenta y comienzos de los ochenta, en el antiguo Instituto de Bellas Artes. $\mathrm{O}$ a los múltiples intentos que luego emprendieron los profesores Eduardo Chavarro y Hernando Rozo, en la Facultad de Bellas Artes, donde los cursos de extensión en plástica, música, literatura, filosofía e idiomas, se convirtieron en pregrados. No así el teatro como un oficio que bien requiere de una profesionalización. Esta situación es paradójica si tenemos en cuenta que, según la crónica ya citada del investigador Luis Enrique Osorio ${ }^{34}$, Jorge Roa Martínez fundó el alma mater con la intención de que se convirtiera en un foco de desarrollo para el teatro, del cual era ferviente admirador.

En esta lista de deudores morosos también debemos anotar a los medios de comunicación del presente, más explícitamente a la prensa escrita, pues atrás quedó el tiempo en que los diarios registraban los eventos escénicos y realizaban un análisis concienzudo de las obras. Atrás quedaron los cronistas especializados en las tablas como Silvio Girón, Eduardo López Jaramillo, Aparicio Posada, Germán Ossa, Nelly Arias de Ossa, Abelardo Gómez y Franklin Molano, entre otros. Hoy a los diarios locales no les interesa apostarle al desagradecido oficio de la crítica teatral y este descuido reafirma el enorme vacío que tiene la ciudad en el campo de la cultura, solo hasta hace poco que esta preocupación la retomó el periódico mensual Ciudad Cultural dirigido por Mauricio Gómez. En este sentido, es de vital importancia que se piense en la necesidad de desplegar un programa específico de formación en esta materia, pero, también, llamar la atención para que los medios de comunicación locales y regionales vuelvan a asumir su papel, tan esencial, de velar por el desarrollo cultural de Pereira.

En fin, con o sin crítica, formación profesional y respaldo estatal, los teatristas pereiranos seguirán enfrentándose al día a día con su recursividad y emprendimiento. Solo con el apoyo institucional se les podría brindar a los artistas la posibilidad de crear obras con todos los requerimientos escénicos que exige el montaje de obras de calidad, y dar un rumbo más acorde con las exigencias del teatro contemporáneo en cuanto a la incursión de nuevos conceptos artísticos y el uso de las últimas tecnologías, que signifique además el inicio de un proceso de innovación, quizá más atrevido, para un gremio que siempre ha dejado en el escenario alma, vida y sombrero. Un gremio, una actividad teatral en cuyos escenarios y obras podemos ver encendidas las luces para seguir contemplando y escribiendo otras páginas, acaso teatrales, es decir, vivas, de la historia cultural de la ciudad y de sus habitantes.

\footnotetext{
${ }^{34}$ Luis Enrique Osorio, “Artistas de Pereira”, El Tiempo, Teatro, Vida cultural (S.F. pero se estima que pudo haberse publicado entre diciembre de 1964 a mayo de 1965).
} 


\section{Bibliografía}

Chisco, René Fernando y Diego Hernando Restrepo. Memorias Primer Mercado Departamental de Arte. Pereira: Colección Literaria del Fondo Mixto para la Promoción de la Cultura y las Artes de Risaralda, 1996.

Esquivel, Catalina. "Teatro La Candelaria: Rasgos de una Dramaturgia Nacional”. Tesis doctoral. Universidad Autónoma de Barcelona, 2010. https://ddd.uab.cat/pub/trerecpro/2010/hdl_2072_97278/Catalina_Esquivel.pdf

García, Santiago. Teoría y práctica del teatro. Bogotá: Ediciones Teatro La Candelaria, Editores Ceis, 1983.

Gil Montoya, Rigoberto. Nido de cóndores: aspectos de la vida cotidiana en los años veinte. Bogotá: Ministerio de Cultura, 2002.

Girón, Silvio. Rastros y rostros del periodismo pereirano. Vol. 6. Pereira: Litografía Prenóbel, Fondo Mixto para la Promoción de la Cultura y las Artes, 1996.

. Los pioneros del periodismo pereirano. Pereira: Instituto Financiero para el desarrollo de Risaralda, 1994.

González Cajiao, Fernando. Historia del teatro en Colombia. Bogotá: Colcultura, 1986.

González, Luis Carlos. Retocando imágenes: 33 crónicas del Pereira Antiguo. Pereira: Fondo Editorial de la Gobernación de Risaralda, 1984.

Jaramillo, María Mercedes. El Nuevo Teatro colombiano: arte y política. Medellín: Universidad de Antioquia, 1992.

Salazar, Lisímaco. Pedacitos de Historia. Pereira: Gráficas Buda, 2013.

Salcedo Silva, Hernando. Crónicas del cine colombiano, 1897-1950. Bogotá: Carlos Valencia Editores, 1971. 


\section{ANEXO 1}

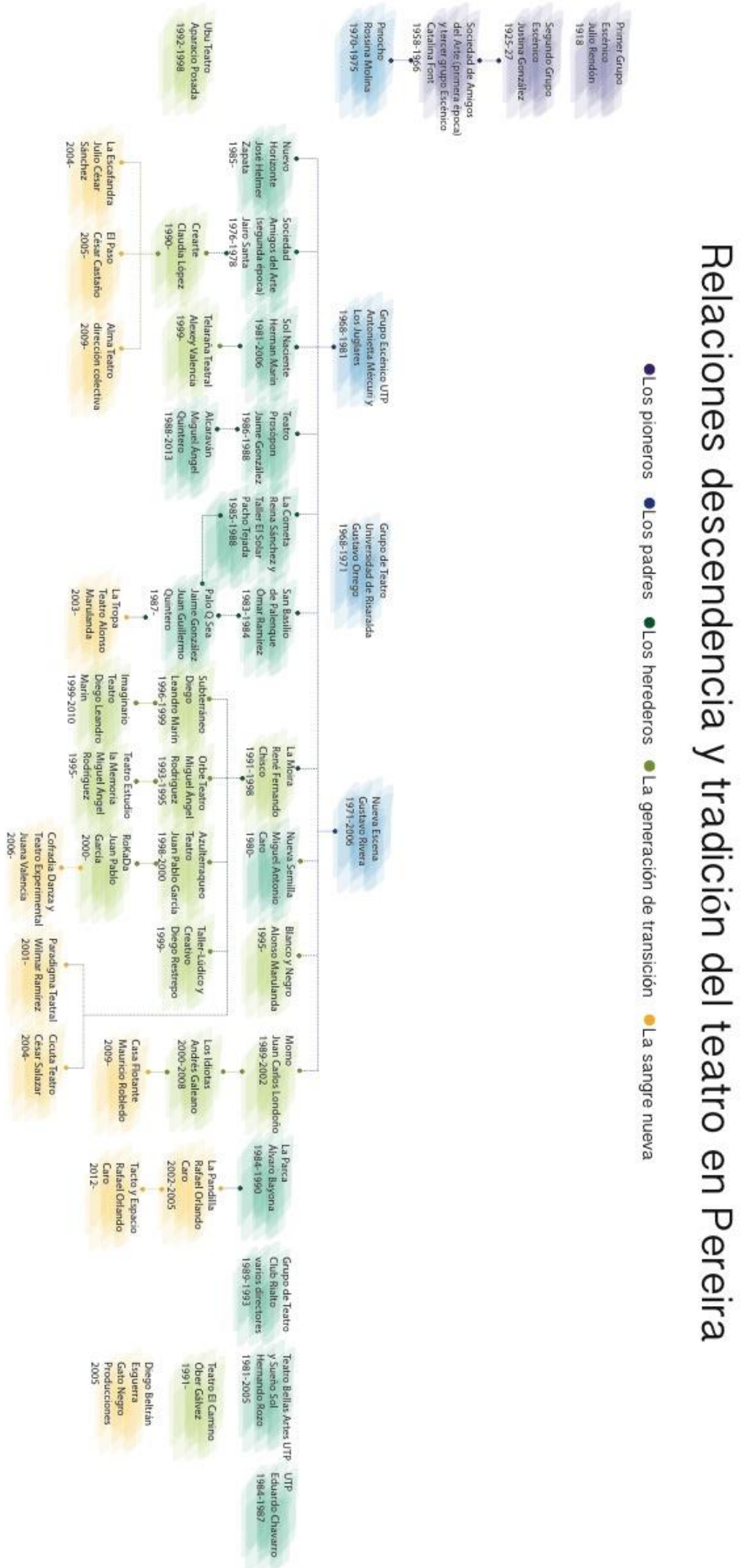




\section{ANEXO 2}

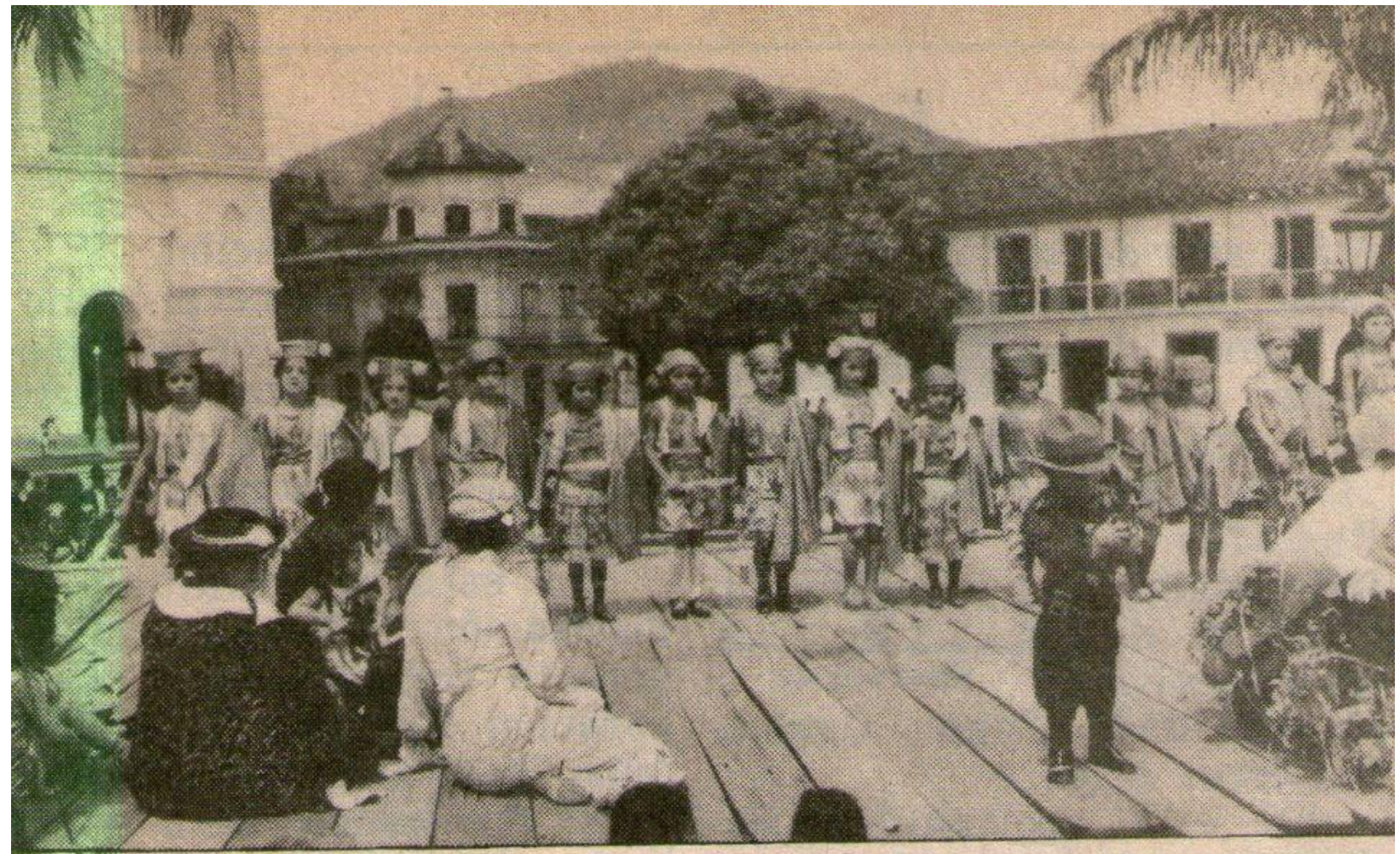

Un espectáculo infantil en escenario levantado en la Plaza de Bolivar. Su antiguedad tiene como referencia el primitivo edificio que se alcanza a ver en la esquina noroeste, luego reformado para albergar al Club Rialto, muchos años antes de su traslado a la sede actual.

Figura 1.

Tinglado en la Plaza de Bolívar década de1930, al fondo la esquina de la calle 20 con carrera séptima. Fuente: Facsímil del periódico El Diario (s.f.). Archivo: Samuel A. Osorio. 


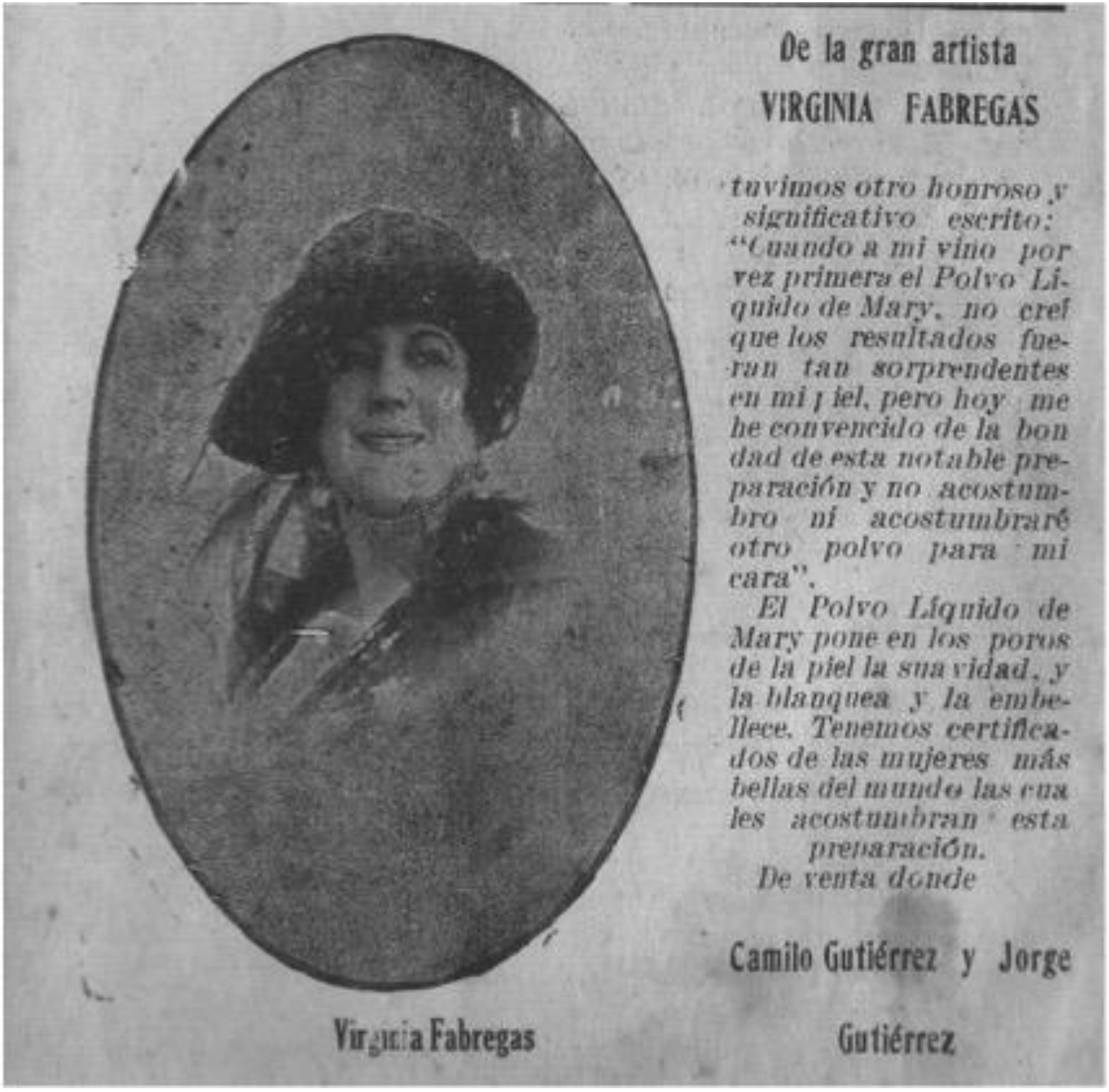

Figura 2.

Publicidad de la presentación de la compañía de Virginia Fábregas.

Fuente: Facsímil de la revista Variedades, No.71, 26 de junio de 1926. 


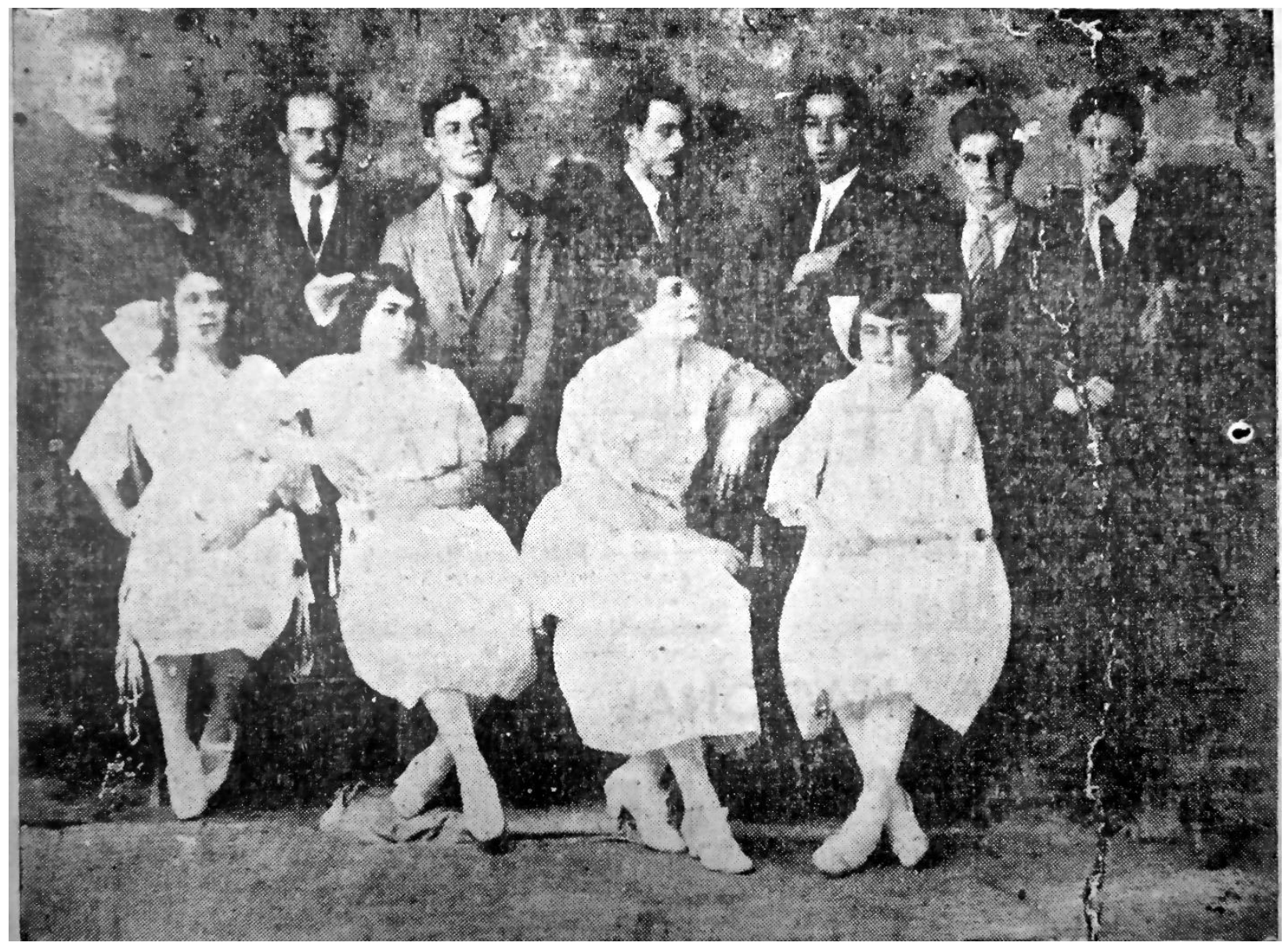

Figura 3.

Integrantes del primer Grupo Escénico. De izquierda a derecha: Julio Rendón E., Horacio Escalante, Arcesio Mazuera Arango, Luis Escalante, Martín Restrepo Márquez, Benjamín Tejada Cano y Emilio Correa Uribe. Sentadas: Esneda Echeverry de Correa, Lola Ángel de Restrepo, Margarita Rodríguez de Cortés y Alicia Gaviria de Olarte. 


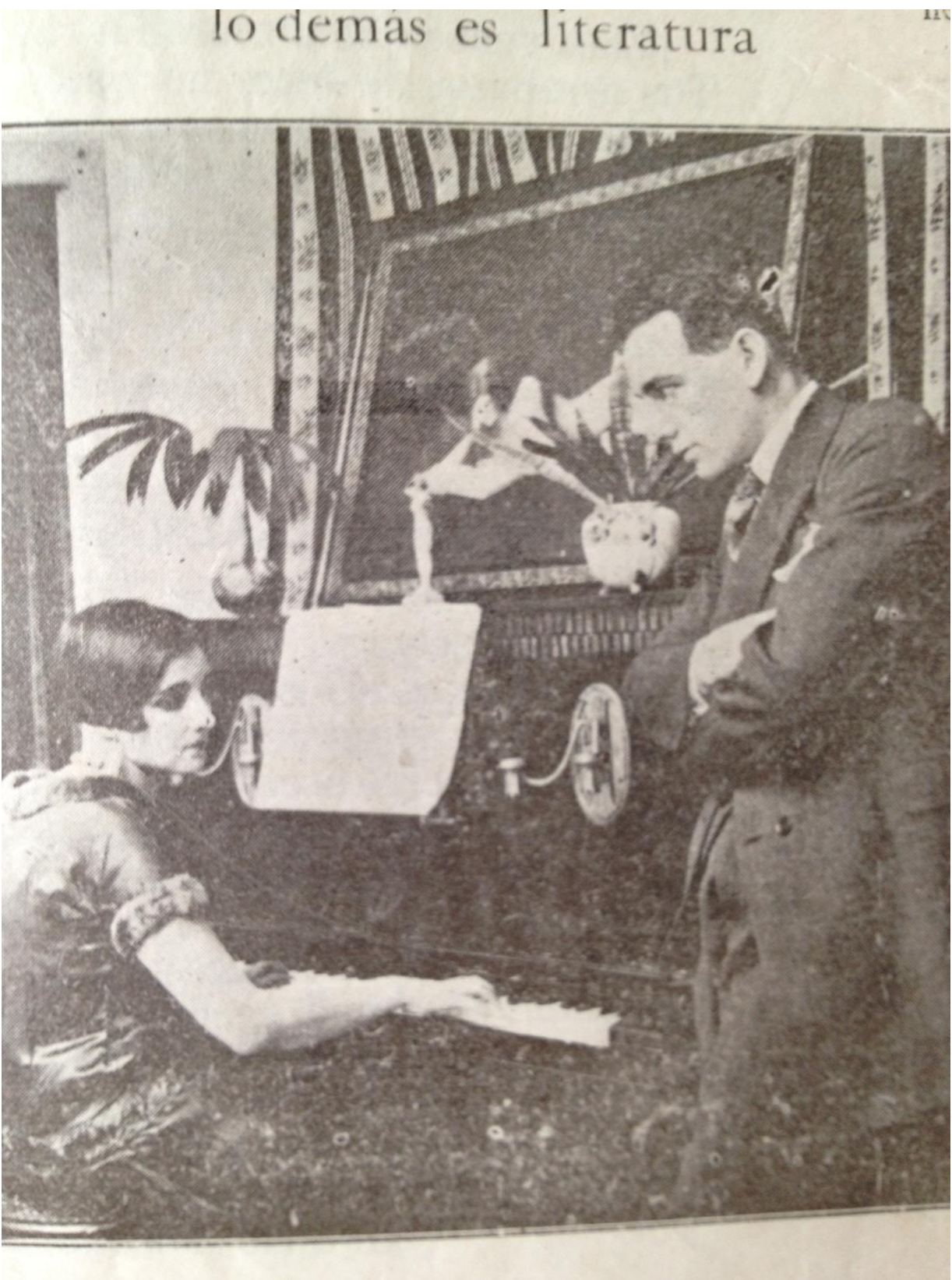

Figura 4.

Único fotograma de la película Nido de Cóndores. La revista Lengua y Raza, anota: "Vista tomada en una escena de la importante película pereirana que se está terminando actualmente".

Fuente: Lengua y Raza, No. 1, 22 de mayo de 1926. 


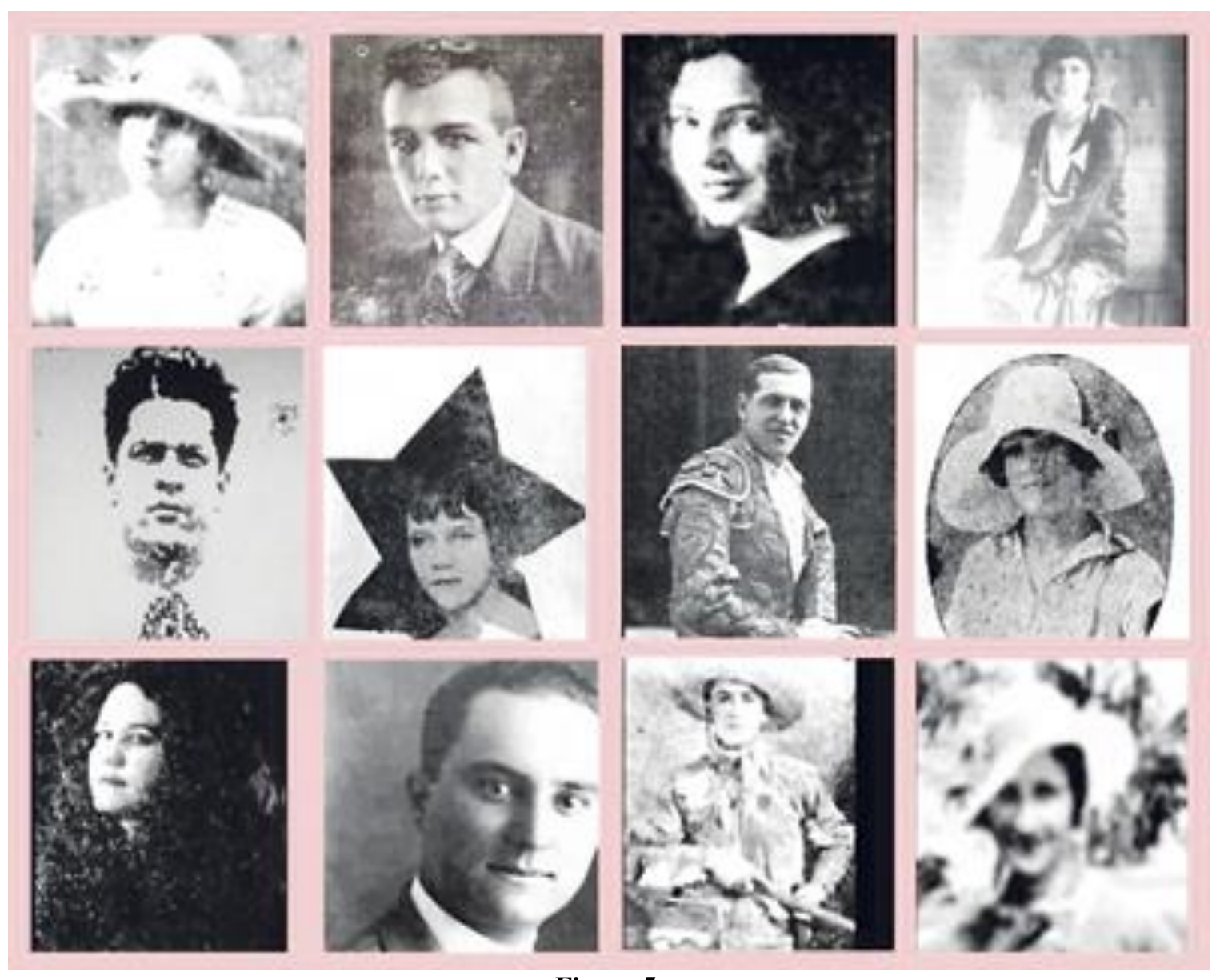

Figura 5.

Elenco de Nido de Cóndores: de izquierda a derecha: Ana Rendón, Fernando Jaramillo, Inés Rendón y Tulia Drews. Segunda fila: Emilio Correa Uribe, Conchita Vélez, Pedro Basauri "Pedrucho" (torero español), Mariella Gutiérrez. Tercera fila: Teresita Restrepo, Abelardo Echeverry, Eduardo Vallejo y Olga Sierra. Fuente: Archivo Diario del Otún. 


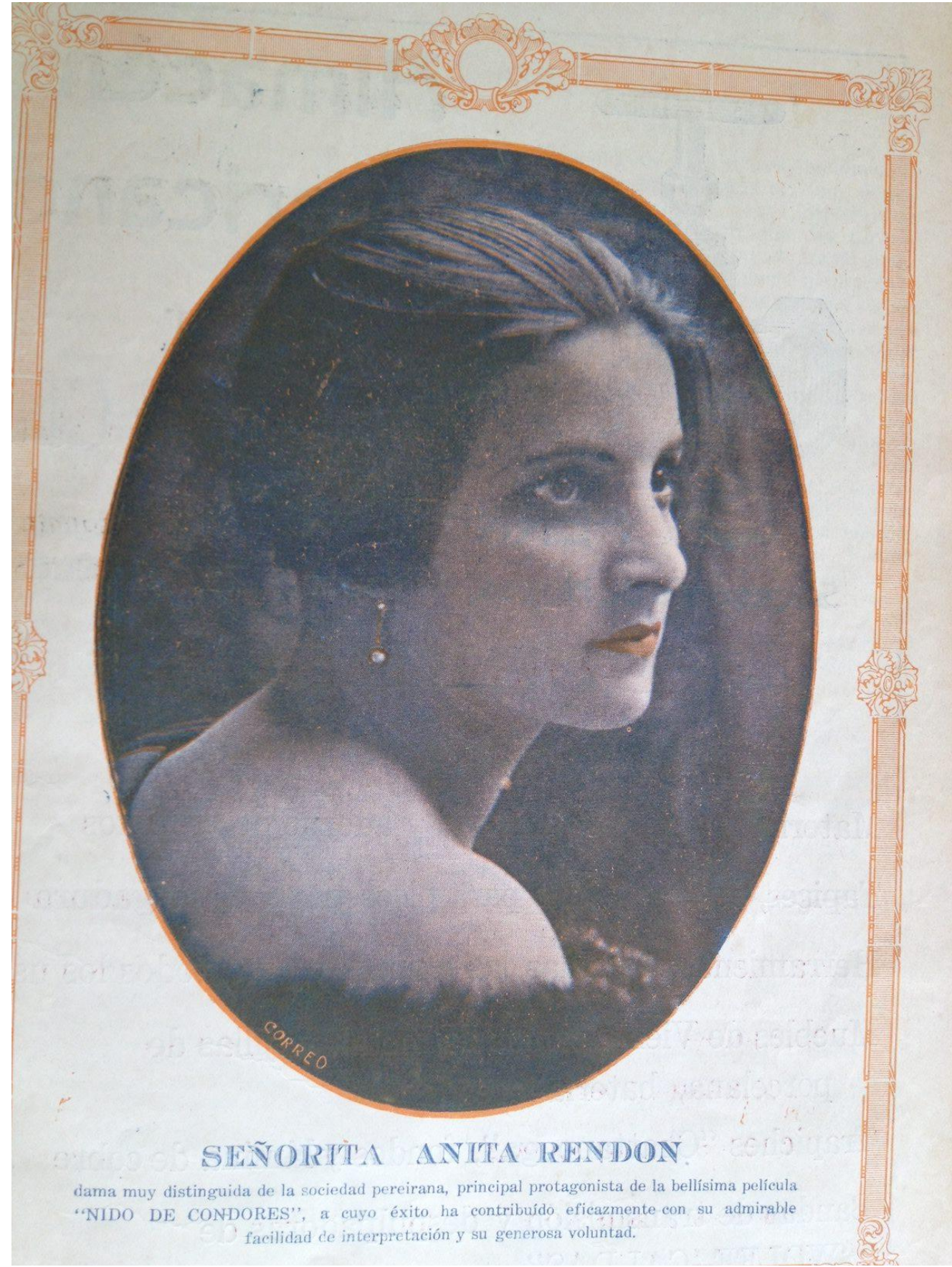

Figura 6.

Portada dedicada a Ana Rendón, protagonista del primer filme silente rodado en Pereira. Fuente: Facsímil de la revista Lengua y Raza No. 1, 22 de mayo de 1926. 


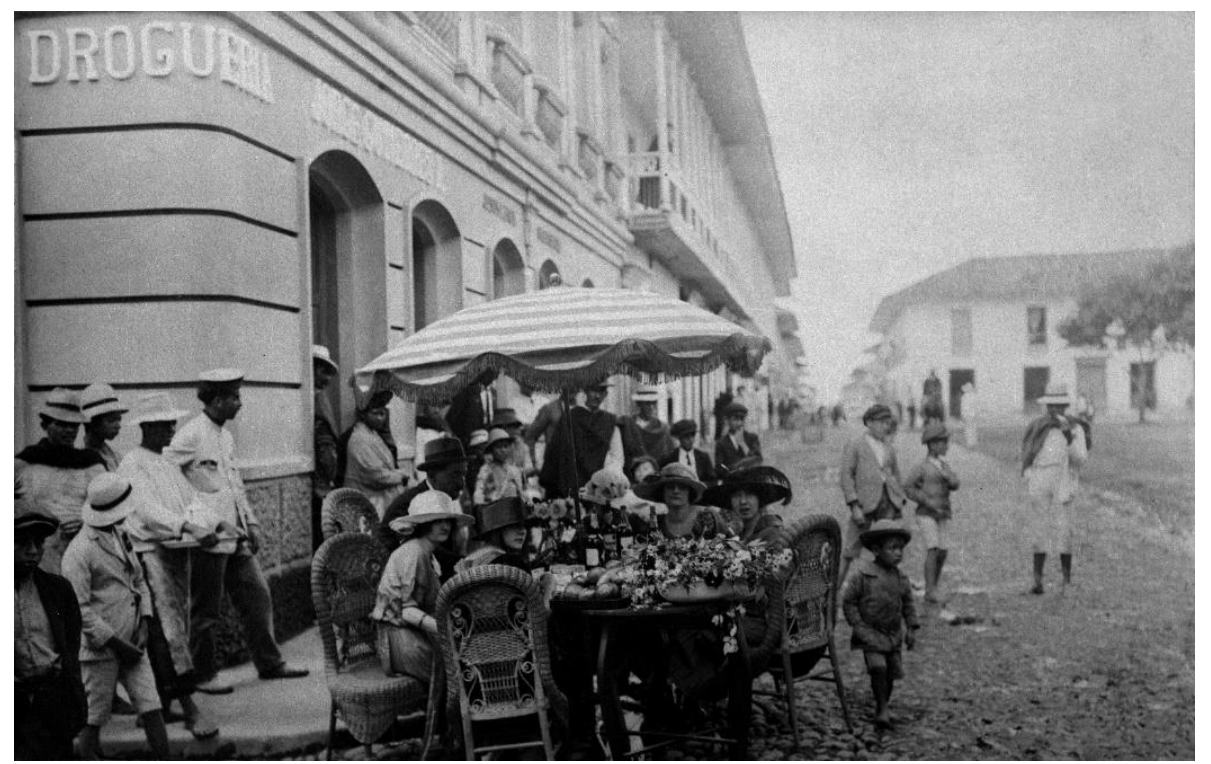

Figura 7.

La kermesse organizada en la esquina de la calle 19 con carrera octava.

Fuente: Archivo Javier García.

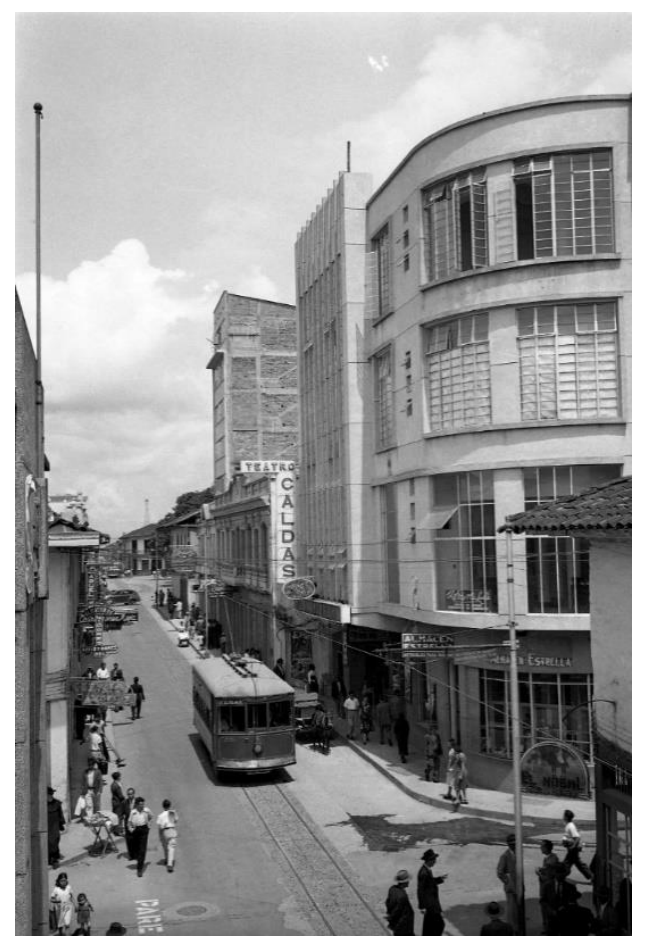

Figura 8.

Pereira años cincuenta, carrera octava entre calles 18 y 19, a la derecha El Teatro Caldas.

Fuente: Foto Donato García. Archivo Javier García. 

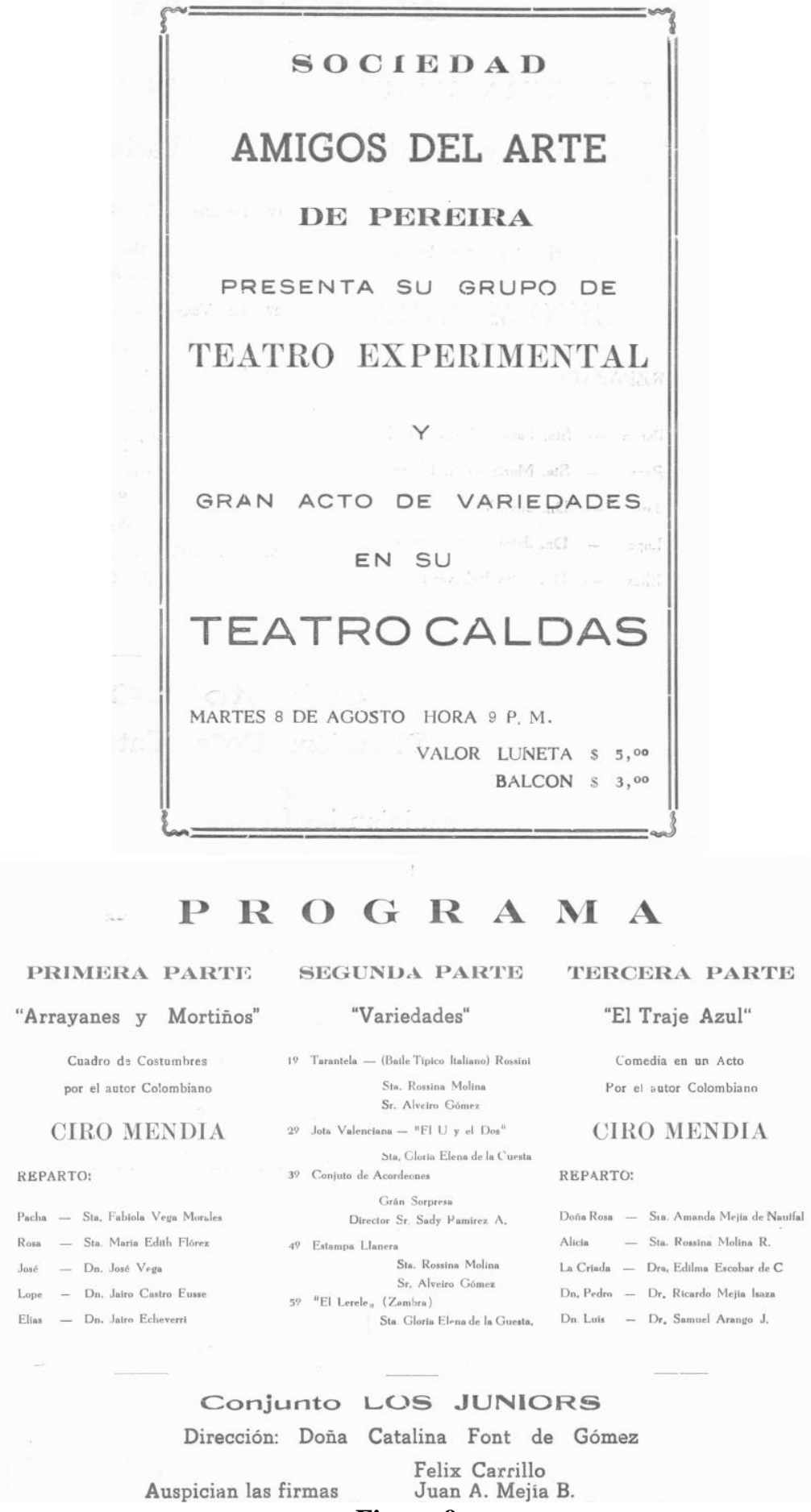

Figura 9.

Volante que anuncia la función de teatro organizada por la Sociedad de Amigos del Arte en los años sesenta.

Fuente: Archivo Pilar Gómez Font. 


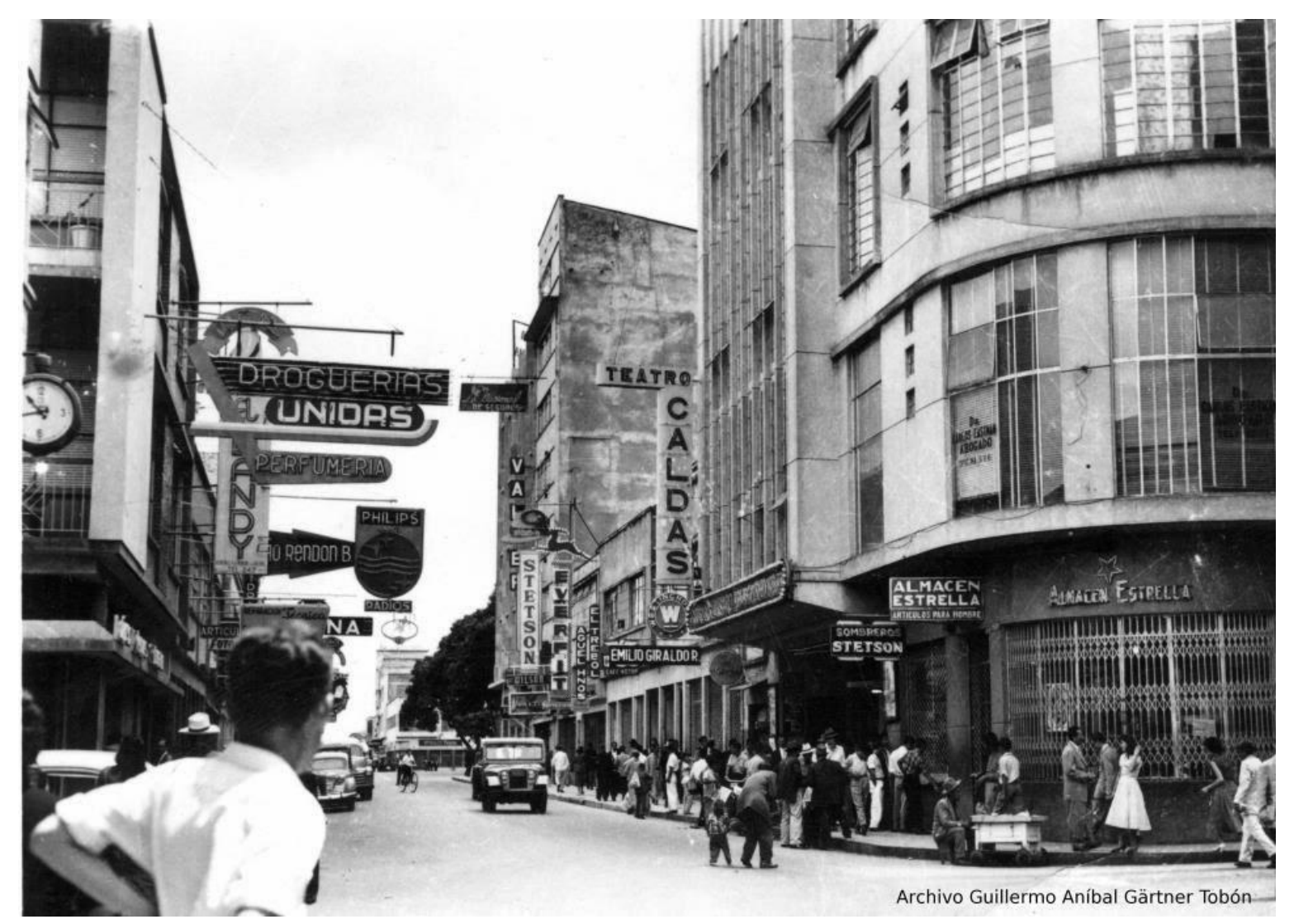

Figura 10.

Pereira años sesenta. Carrera octava entre calles 18 y 19, a la derecha el Teatro Caldas. Fuente: Foto Donato García. Archivo Guillermo Aníbal Gätner Tobón. 


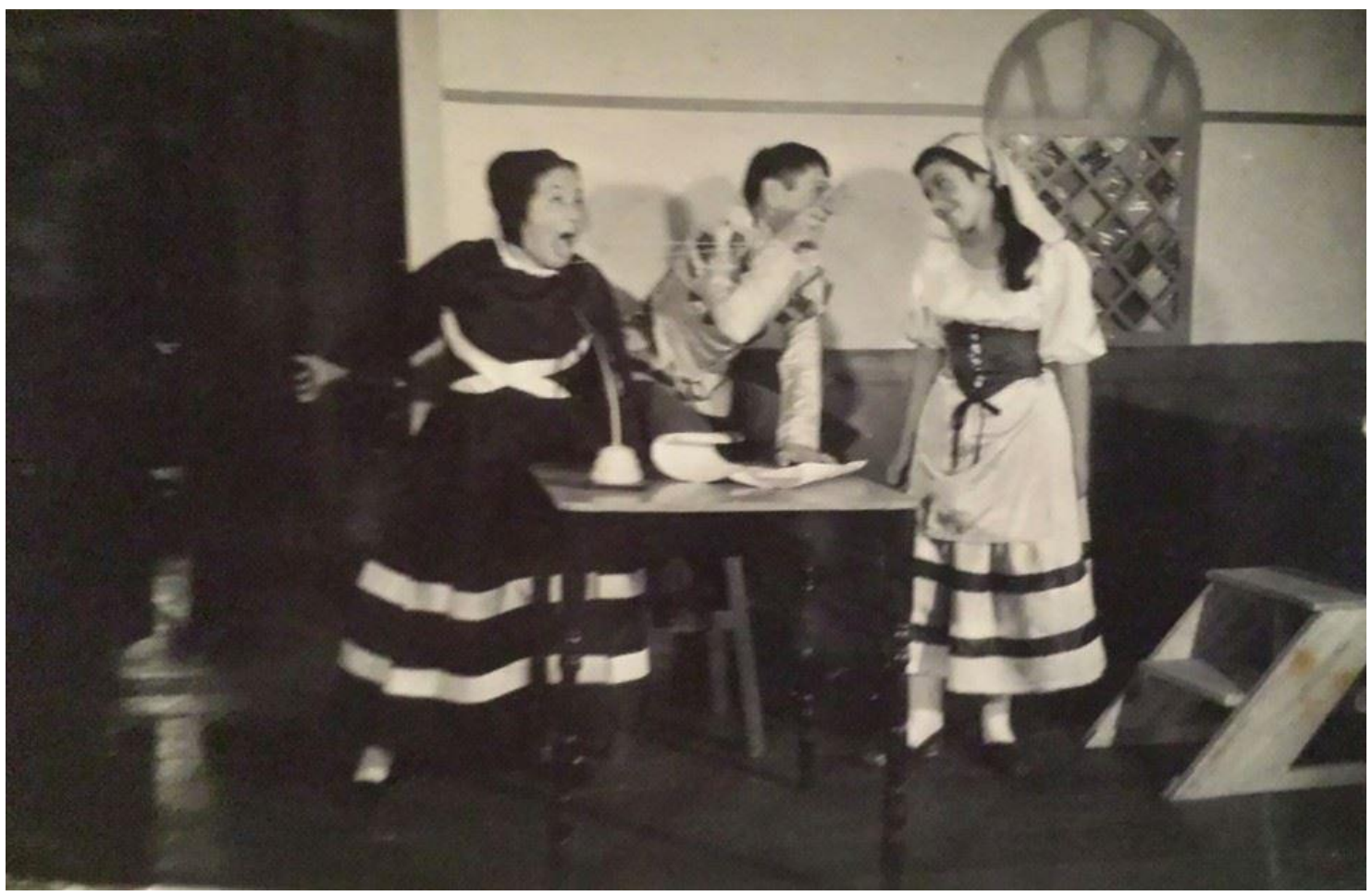

Figura 11.

Escena de la obra de teatro La Tinaja de Luigi Pirandello, en la sala de la Sociedad de Amigos del Arte. Fuente: Archivo Rossina Molina. 


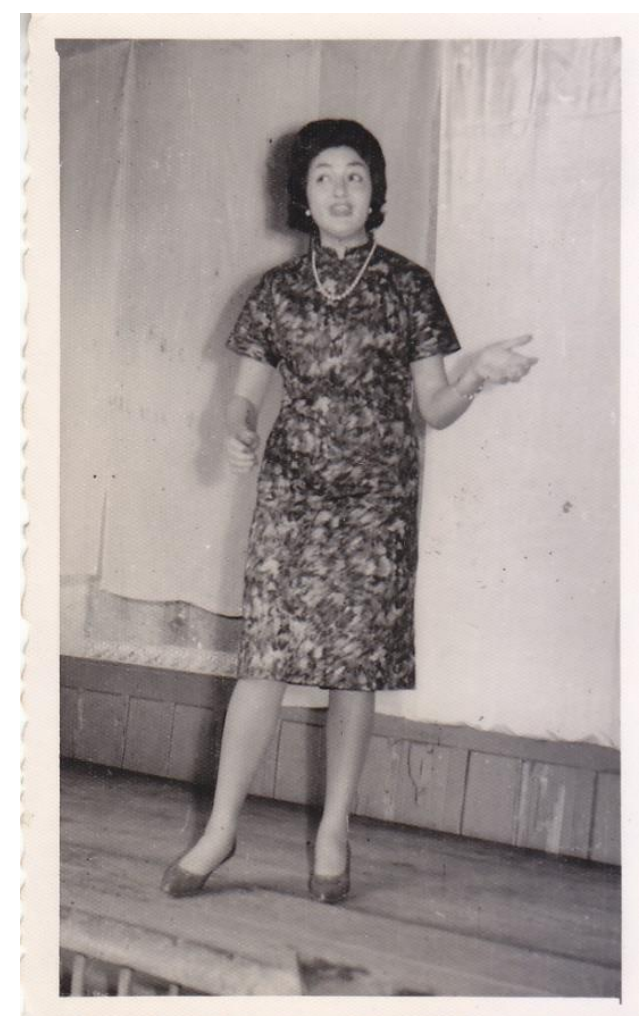

Figura 12.

Catalina Gómez Font declamando poesía en Pereira.

Fuente: Archivo Alberto Gómez Font.

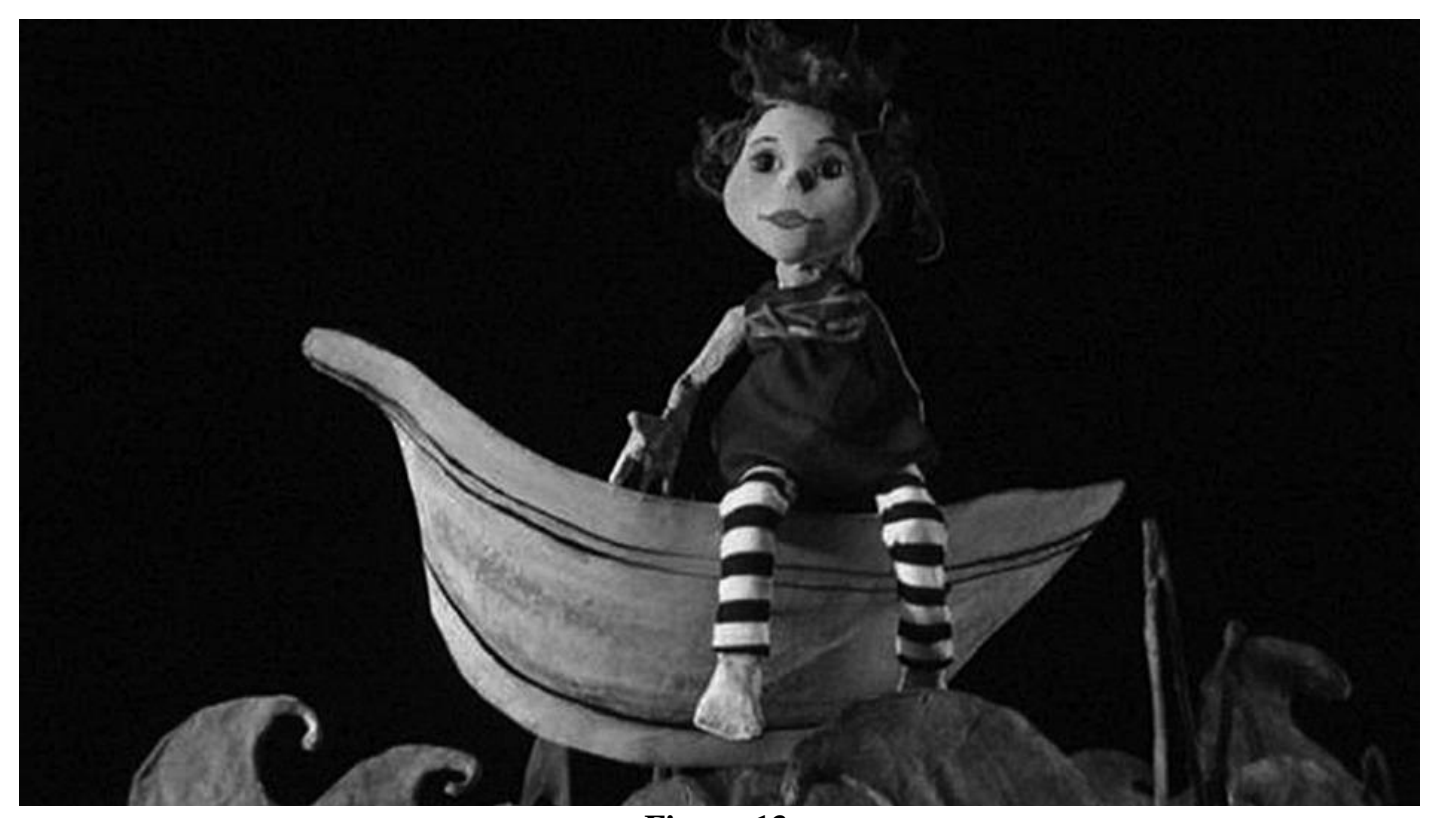

Figura 13.

Obra de muñecos del grupo Jim's Patelin, dirigido por Neverg Londoño en la Sociedad Amigos del Arte. Fuente: Archivo Jesús Calle. 


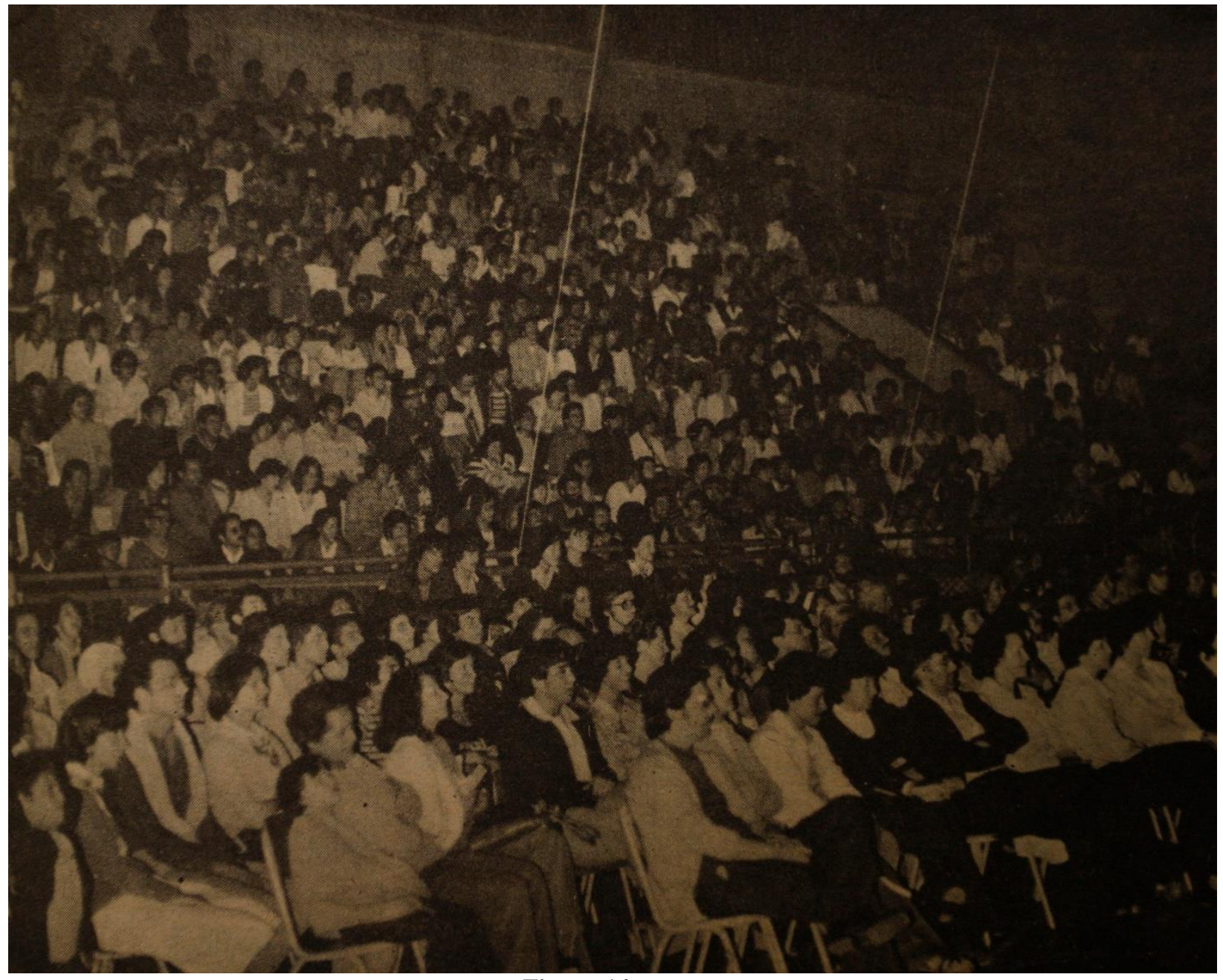

Figura 14.

En la imagen se observa la cantidad de personas que asistieron al montaje Testimonios, de los Mimos de Uruguay y Francia.

Fuente: Facsímil del periódico La Tarde, 20 de septiembre de 1977. 


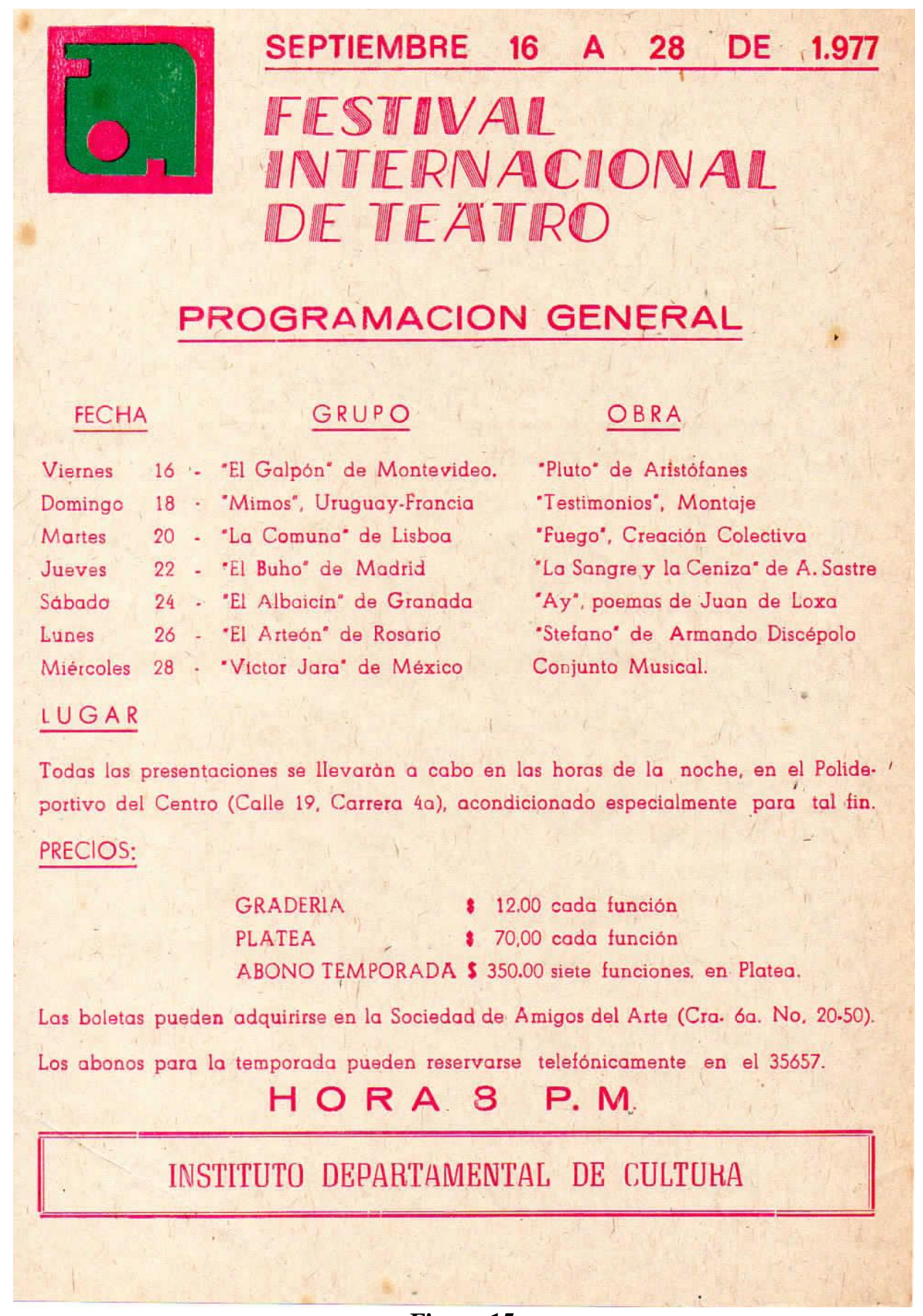

Figura 15.

Facsímil del volante del Primer Festival Internacional de Teatro realizado por la Sociedad de Amigos del Arte en septiembre de 1977.

Fuente: Archivo Academia Pereirana de Historia. 


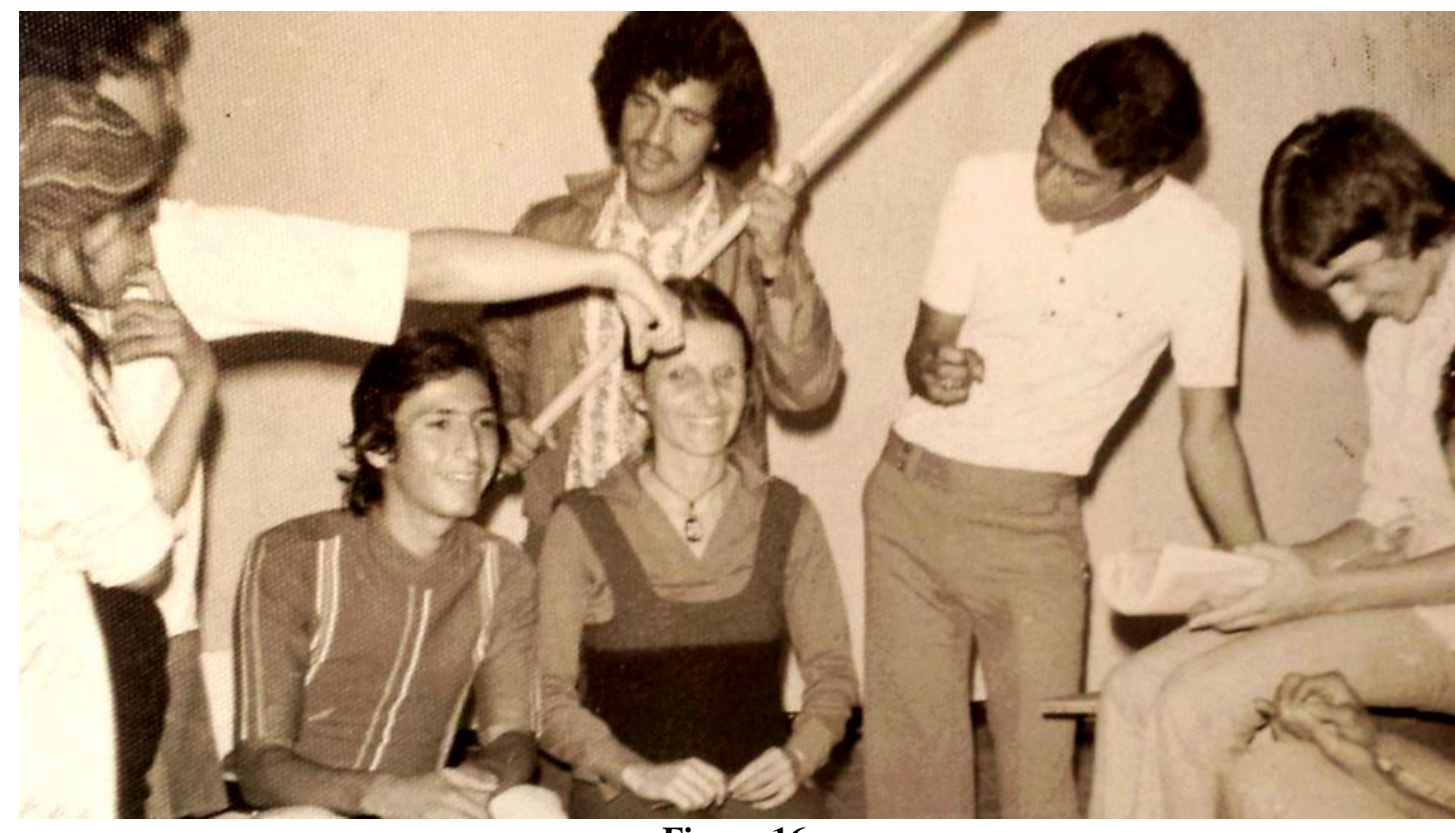

Figura 16.

Grupo de Teatro de la Universidad Tecnológica de Pereira, durante los ensayos. En la foto está Antonietta Mercuri rodeada de sus alumnos.

Fuente: Archivo Igino Mercuri.

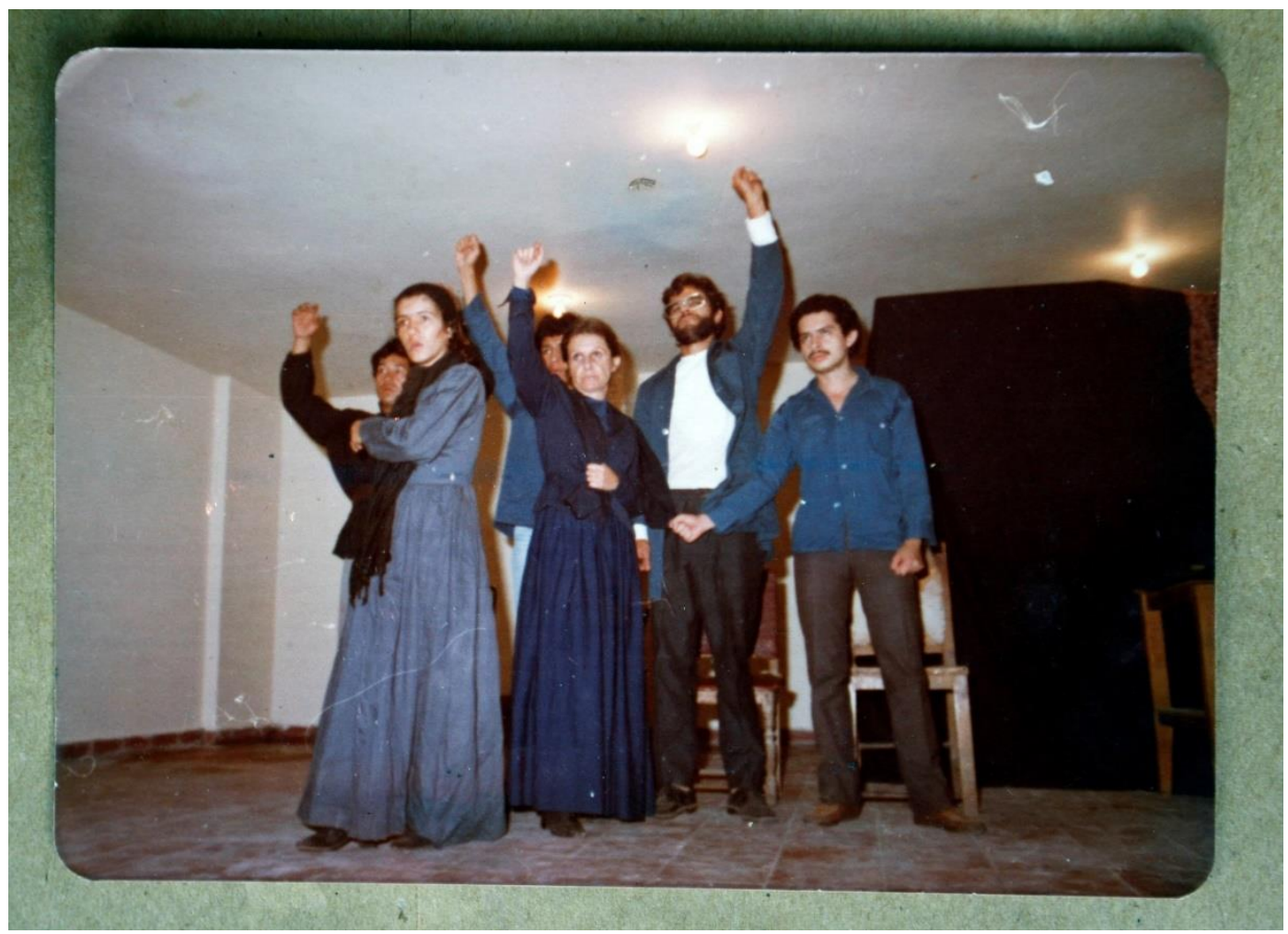

Figura 17.

Presentación de La Madre de Máximo Gorki. En la foto: Reina Sánchez, Antonietta Mercuri, Delio Duque, José Joaquín Montoya, Juan Morales.

Fuente: Archivo Reina Sánchez. 


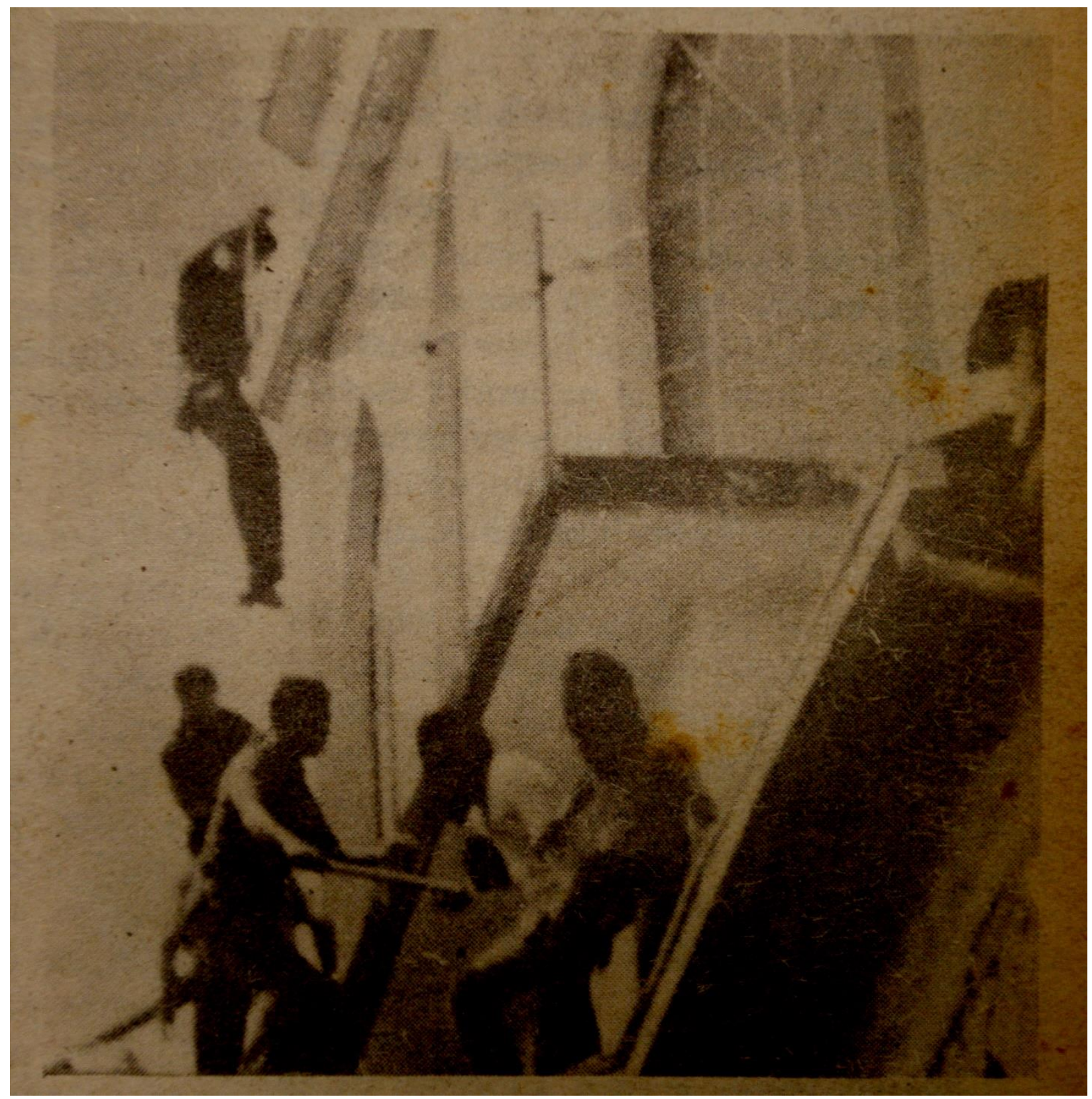

Figura 18.

Imagen del desalojo de los estudiantes por parte de la policía, en la toma de la iglesia San Antonio María Claret.

Fuente: Facsímil del periódico La Tarde de junio 11 de 1981. 


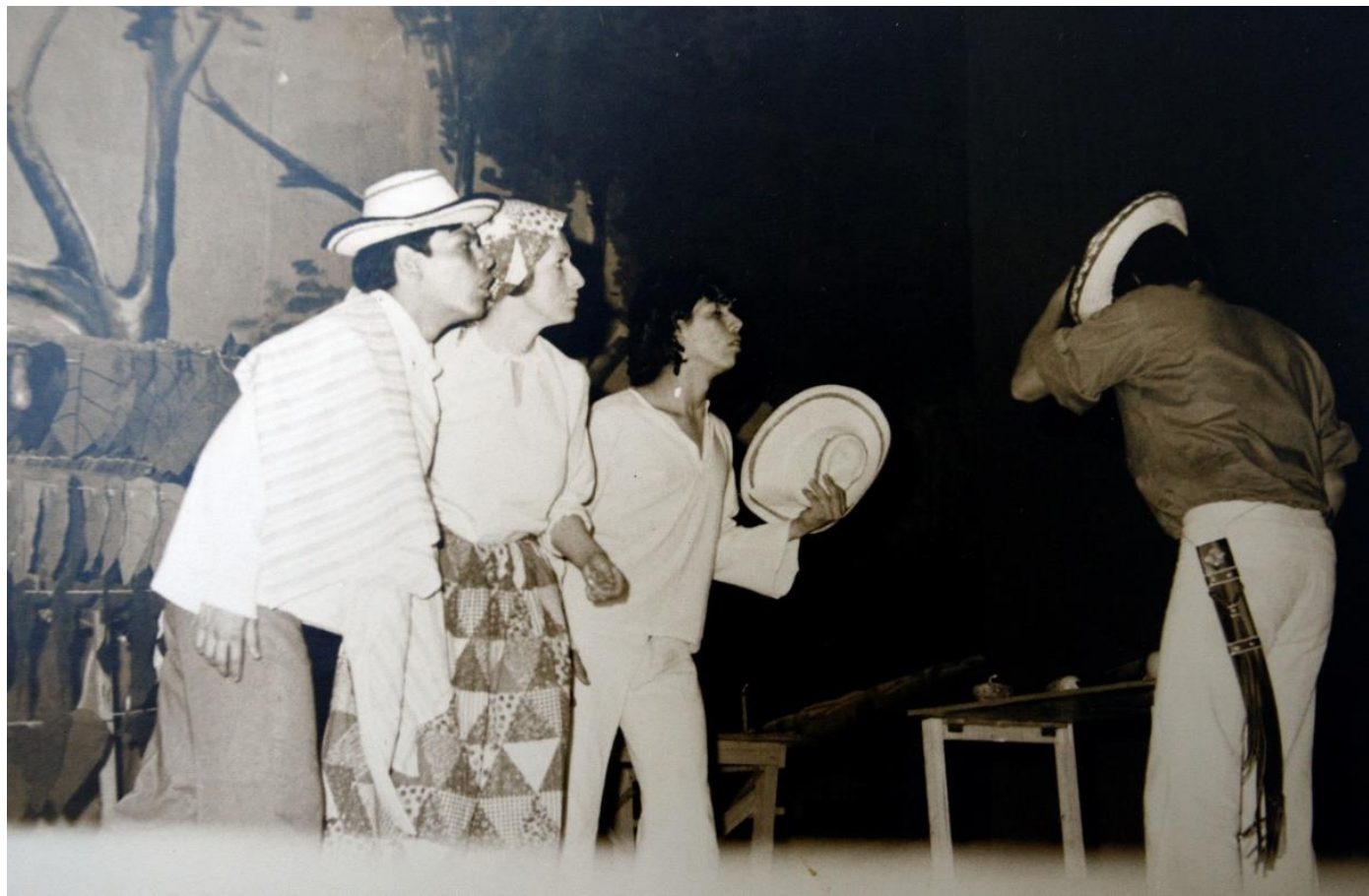

Figura 19.

Escena de El caney del totumo del grupo del Instituto Departamental de Cultura en el Festival Nacional de Teatro Costumbrista.

Fuente: Archivo Gustavo Rivera.

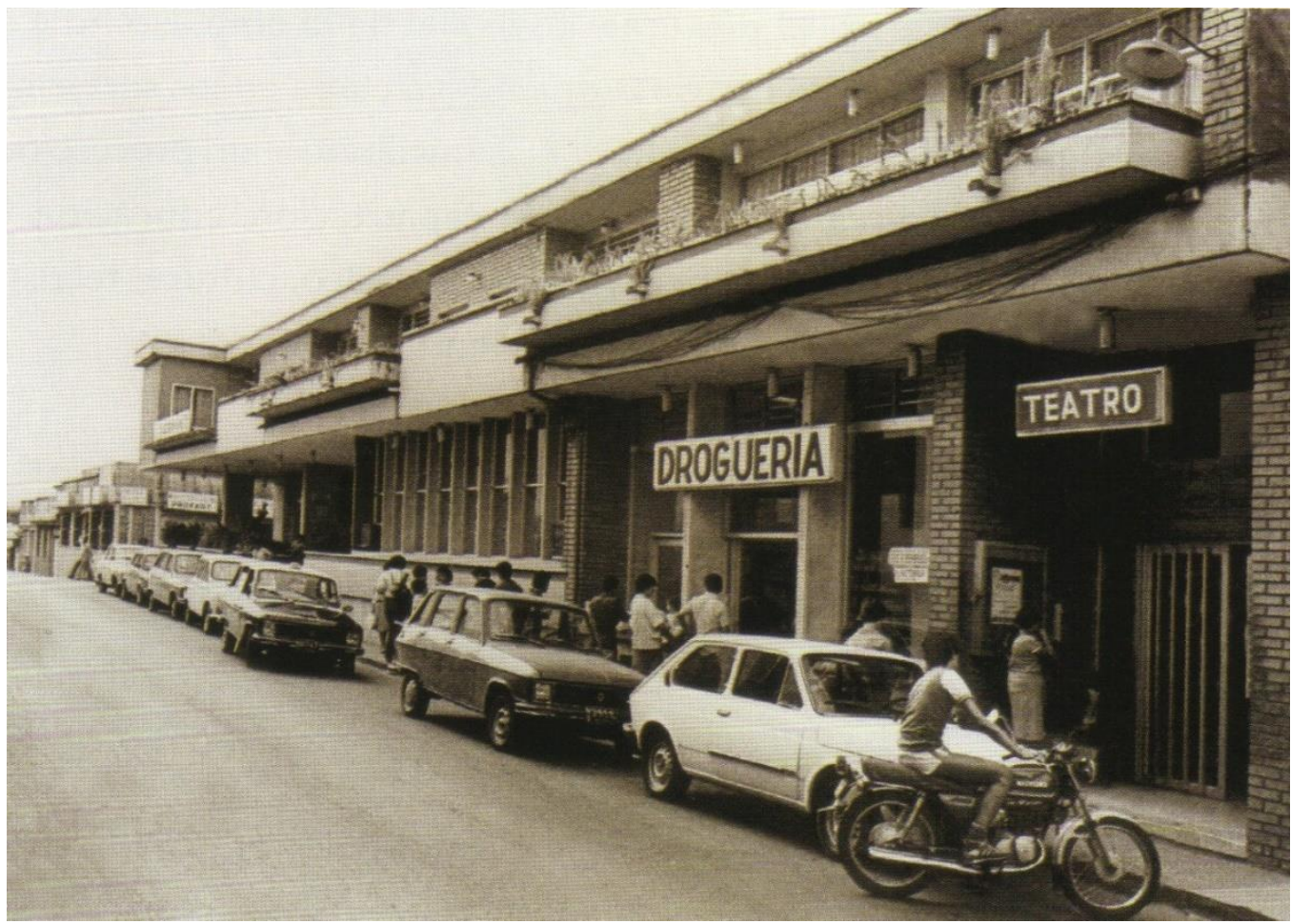

Figura 20.

Entrada al teatro Comfamiliar Risaralda años ochenta.

Fuente: Archivo Comfamiliar Risaralda. 
Hallazgos de un reportaje sobre el teatro pereirano

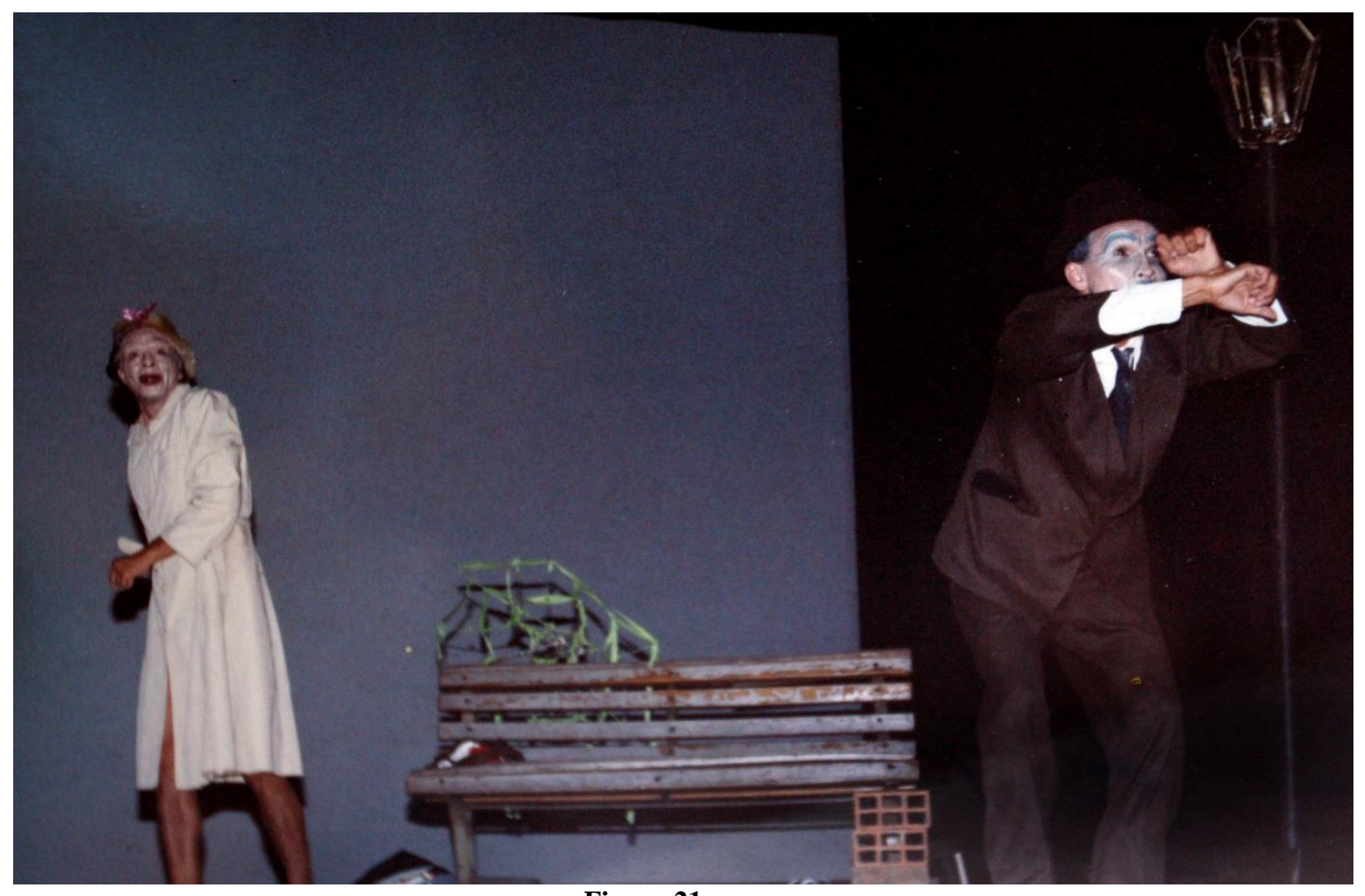

Figura 21.

Cuadro de la adaptación La Joven Casadera de Eugene Ionesco. Fuente: Archivo Gustavo Rivera. 


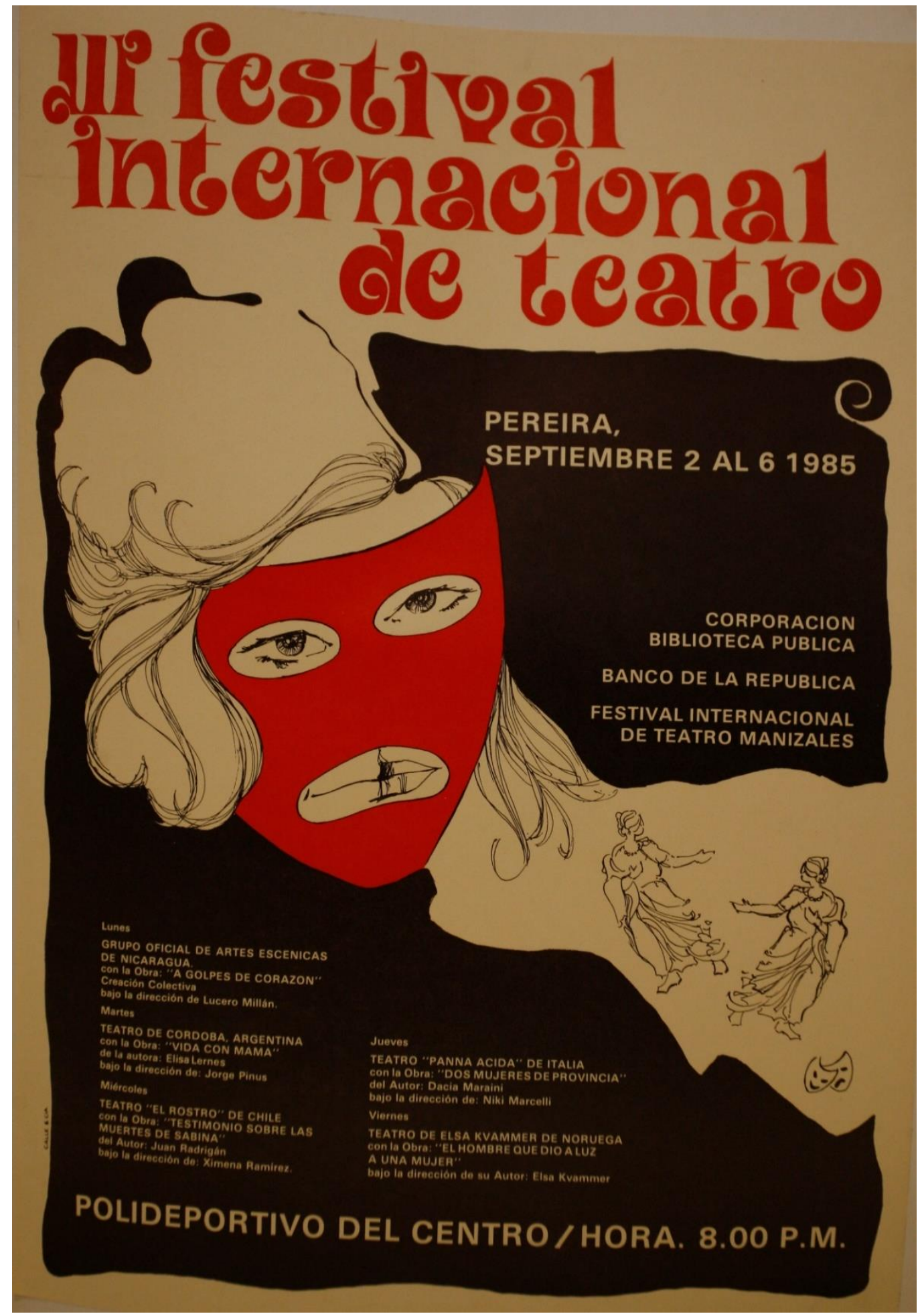

Figura 22.

Facsímil del póster publicitario del Tercer Festival Internacional de teatro, realizado en 1985. Fuente: Archivo Hemeroteca Haidee Jaramillo de la biblioteca pública Ramón Correa. 


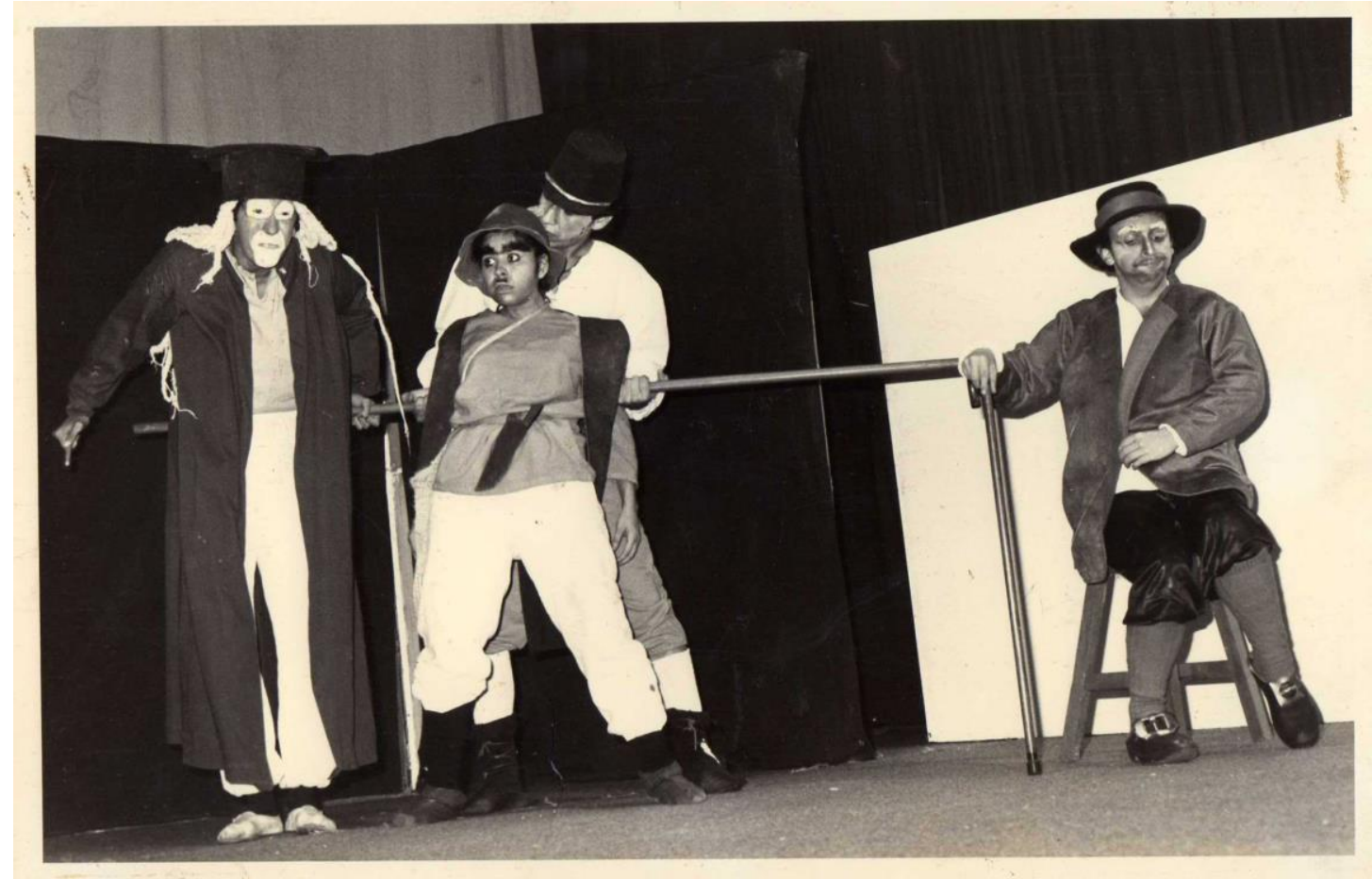

Figura 23.

Cuadro de la obra Farsa del abogado Patelín del Taller UTP en 1984.

Fuente: Archivo Eduardo Chavarro.

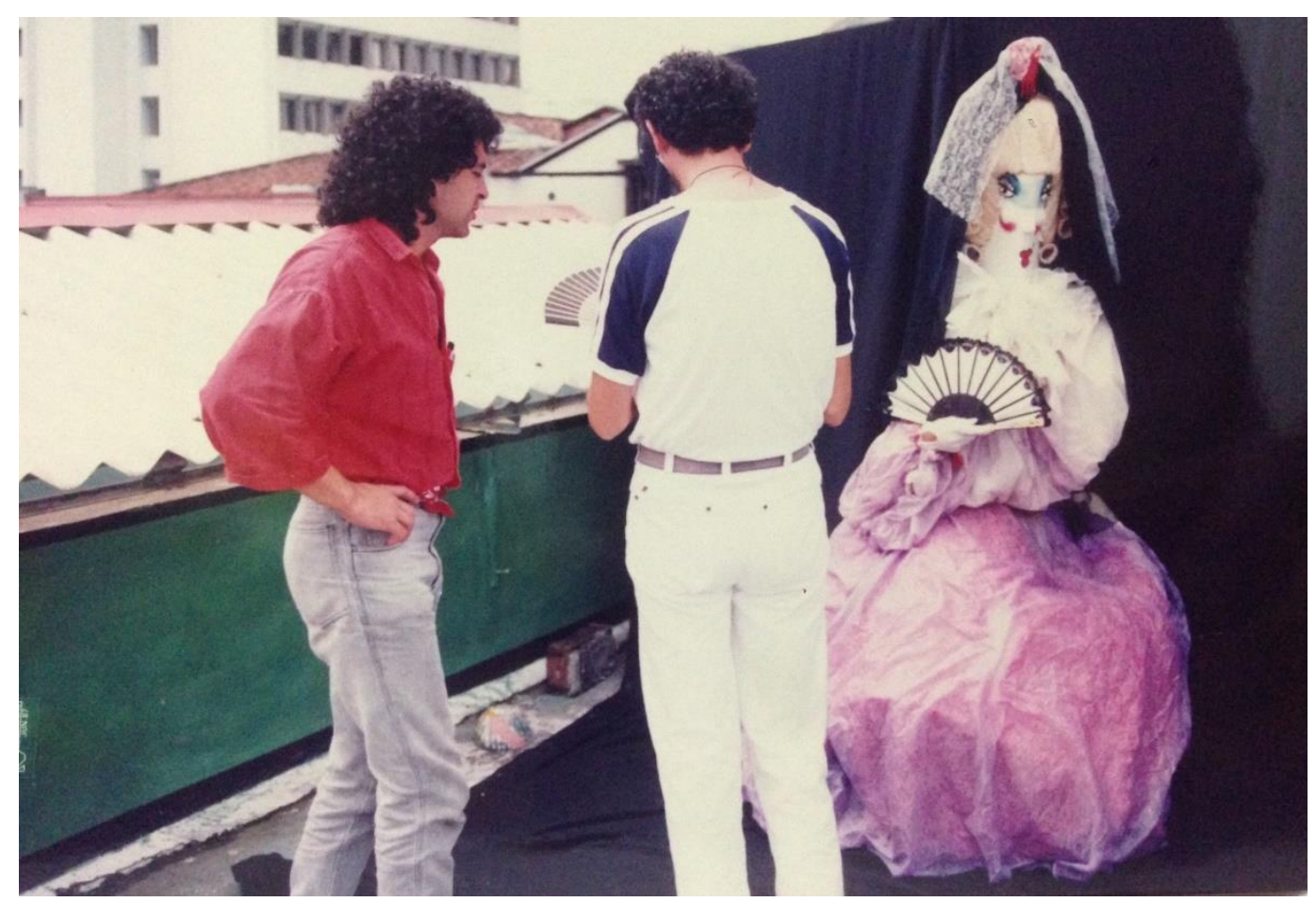

Figura 24.

Pacho Tejada y el Flaco Marín antes de la presentación de El Retablillo de Don Federico. Fuente: Archivo Ana María Arenas. 


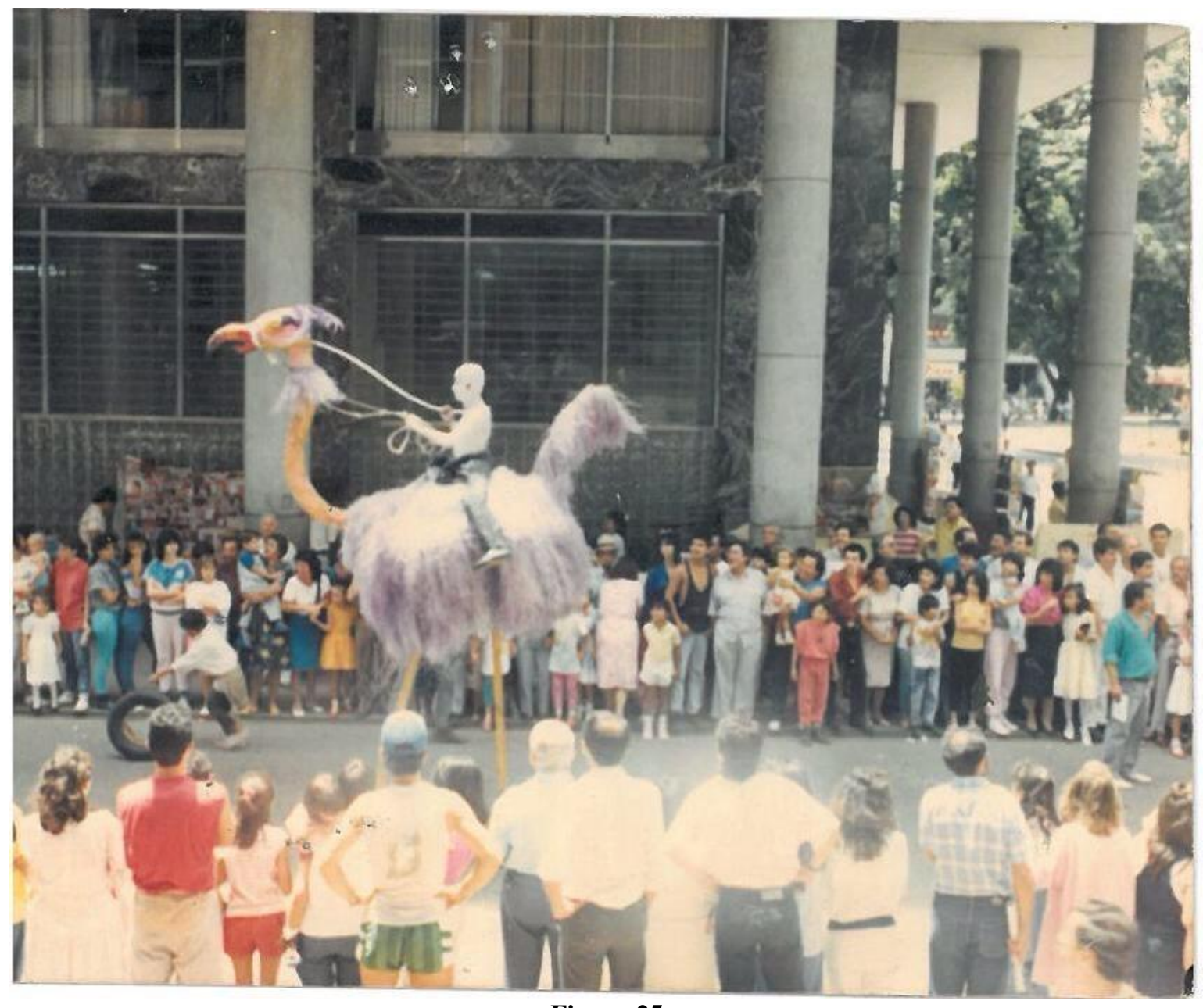

Figura 25.

Palo Q' Sea durante el desfile Pereira de Carnaval en 1987.

Fuente: Archivo Dahiana Gaviria. 


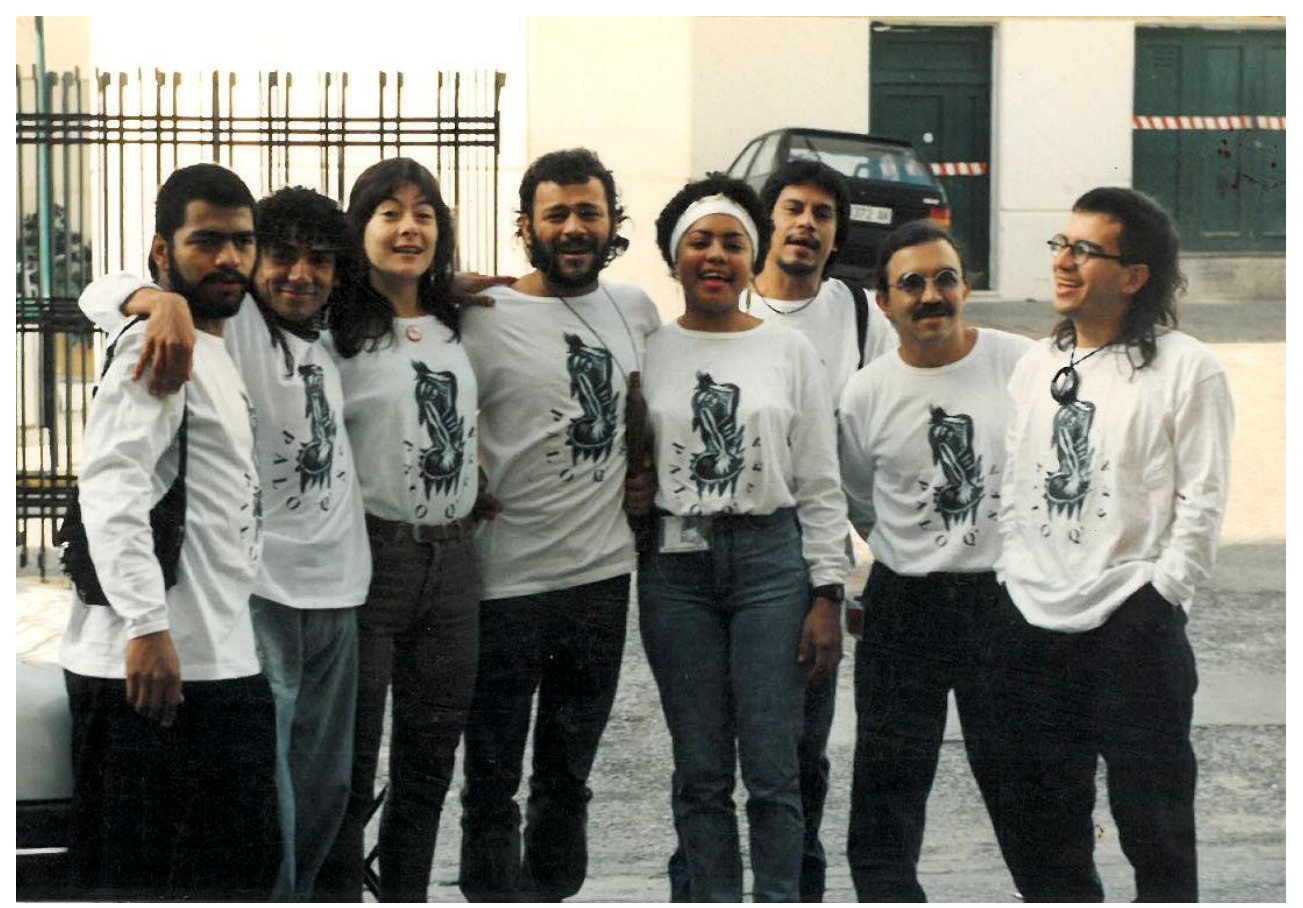

Figura 26.

Palo Q' Sea en el Festival Iberoamericano de Cádiz 1990, de izquierda a derecha: Luis Eduardo Varela, Misael Gaviria, Patricia Ramírez, Jaime González, Claudia Naranjo, Mario Hernán Salazar y César Álvarez. Fuente: Archivo Dahiana Gaviria.

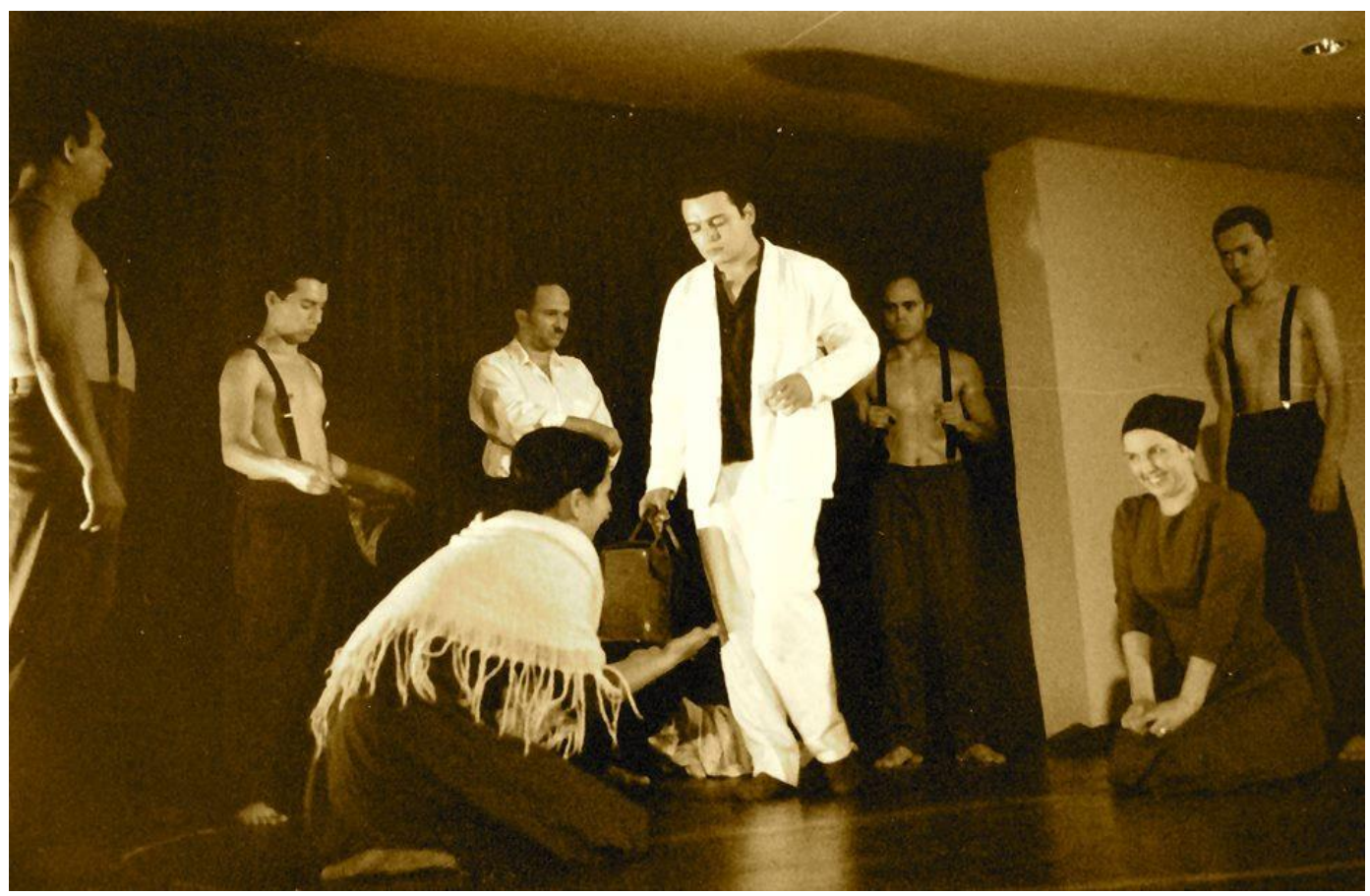

Figura 27.

Escena de la obra El paseo de Federico de Momo Teatro dirigido por Juan Carlos Londoño en 2003. 


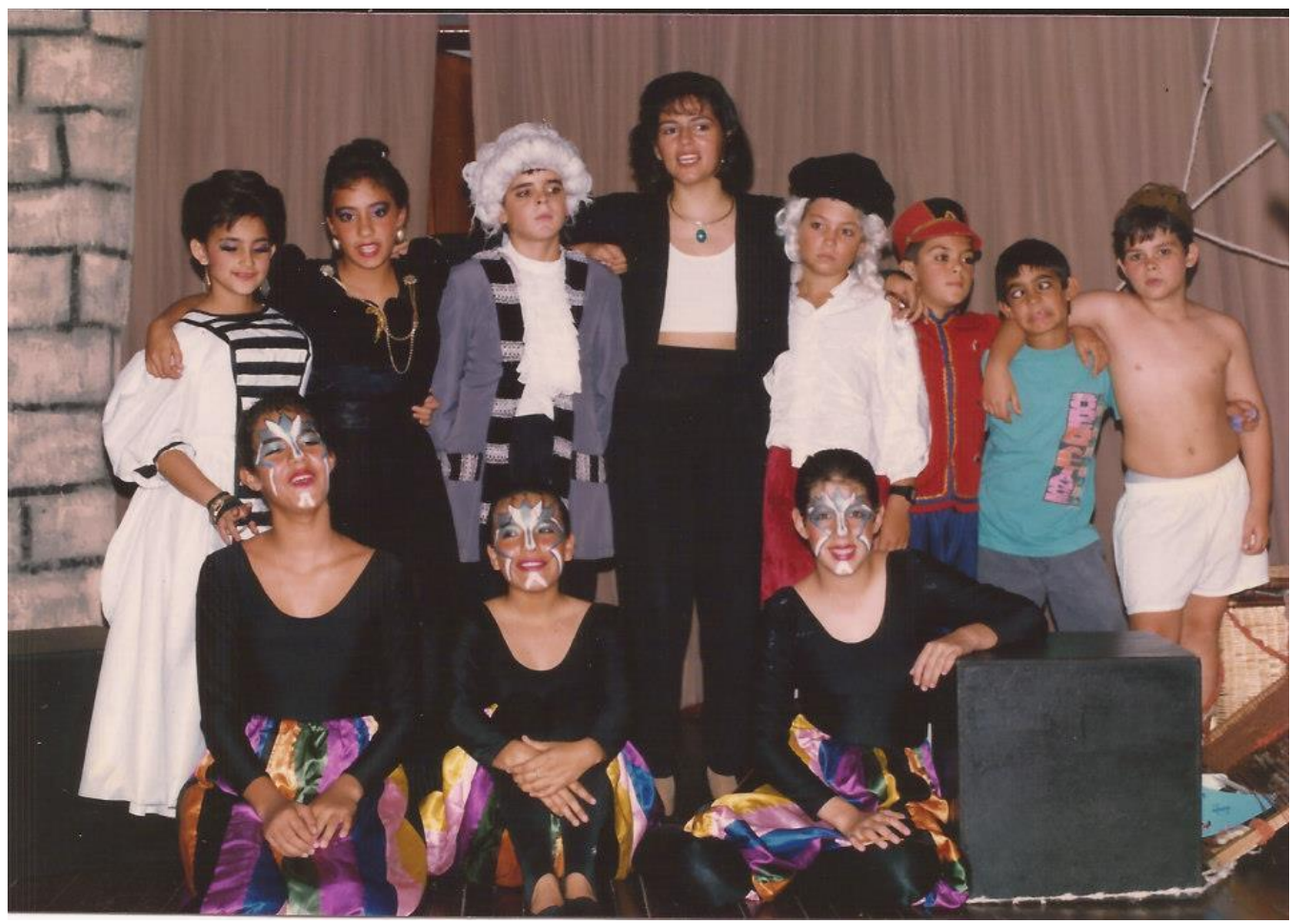

Figura 28.

Claudia López en compañía de sus estudiantes del Grupo Escuela del Instituto de Cultura de Pereira años noventa.

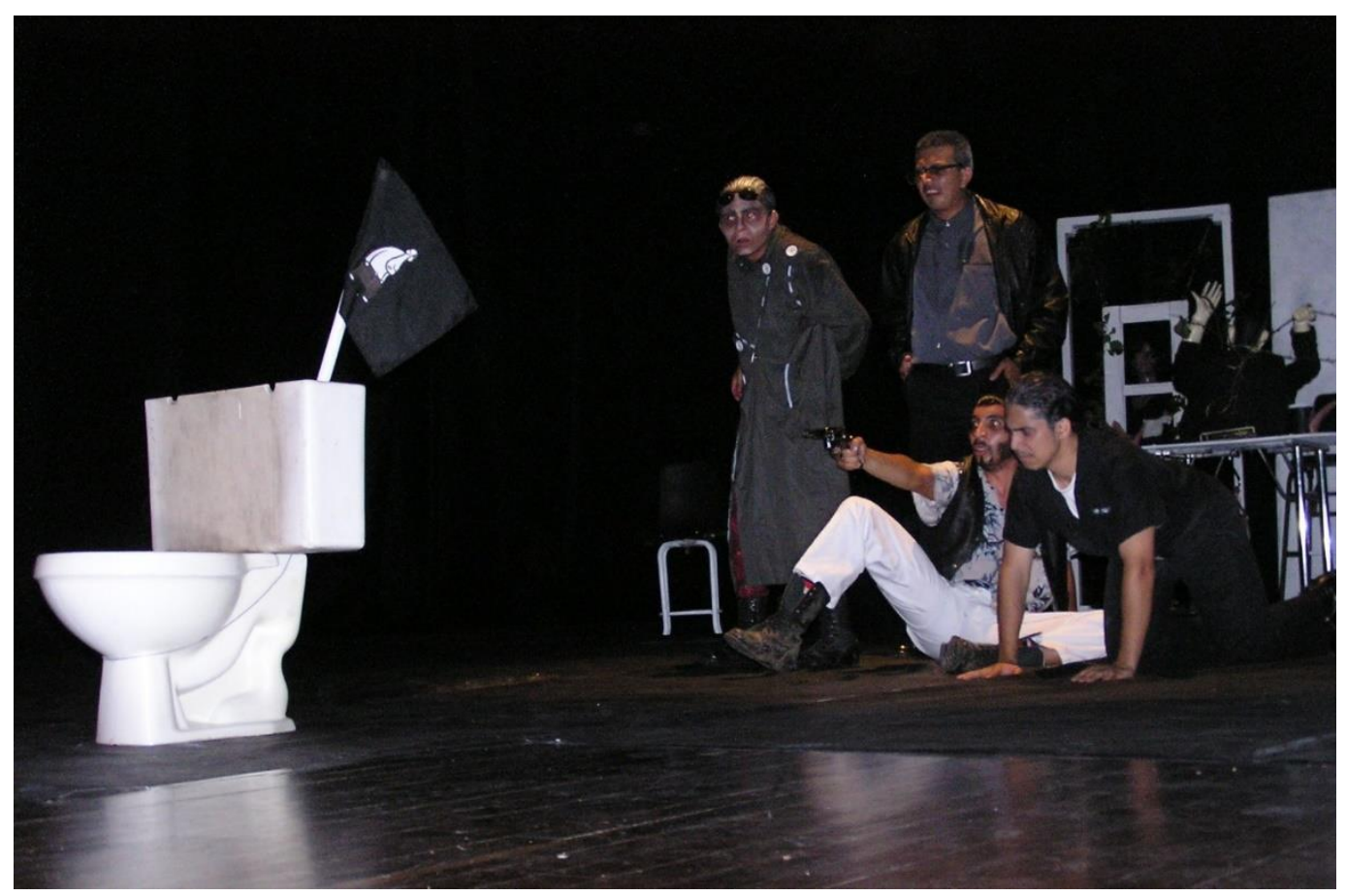

Figura 29.

Obra Caosmos de Los Idiotas Teatro dirigida por Andrés Galeano a comienzos del nuevo milenio. Fuente: Archivo Andrés Galeano. 


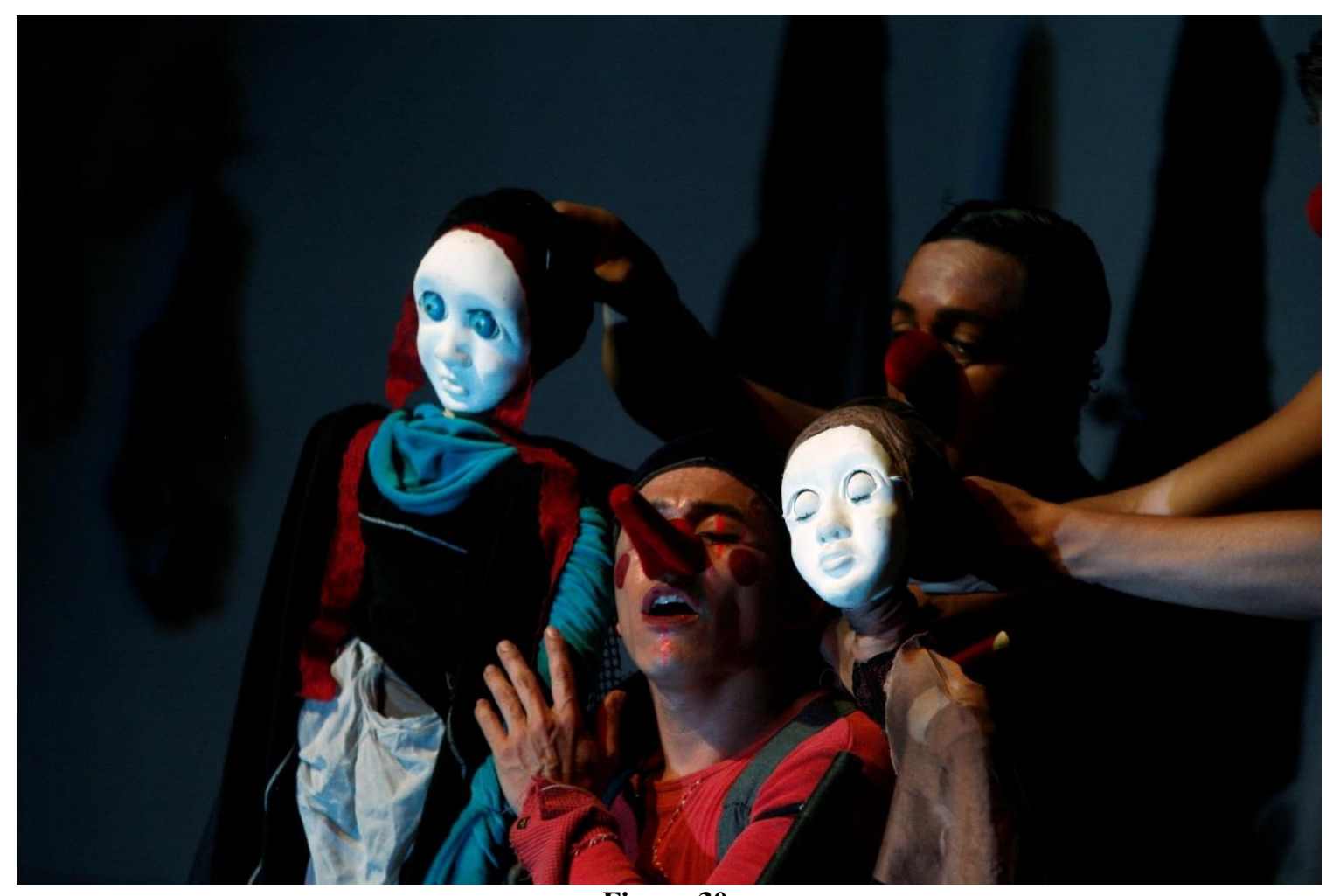

Figura 30.

Adaptación de Pinocho por Tropa Teatro dirigido por Alonso Mejía en el 2013.

Fuente: Fotografía Javier Nieto. 